\title{
E-Government Information Systems (IS) Project Failure in Developing Countries: Lessons from the Literature
}

\section{Joseph B. Nyansiro}

Doctoral student, Department of Computer Science and Engineering,

University of Dar es Salaam

iD https://orcid.org/0000-0003-1523-7601

\section{Joel S. Mtebe}

Associate Professor, Department of Computer Science and Engineering,

University of Dar es Salaam

(iD https://orcid.org/0000-0003-2760-7673

\section{Mussa M. Kissaka}

Senior Lecturer, Department of Electronics and Telecommunication Engineering,

University of Dar es Salaam

(iD https://orcid.org/0000-0002-8607-7556

\begin{abstract}
E-government information systems (IS) projects experience numerous challenges that can lead to total or partial failure. The project failure factors have been identified and studied by numerous researchers, but the root causes of such failures are not well-articulated. In this study, literature on e-government IS project failures in developing-world contexts is reviewed through the application of qualitative meta-synthesis, design-reality gap analysis, and root cause analysis. In the process, 18 causal factors and 181 root causes are identified as responsible for e-government IS project failures. The most prevalent of the 18 causal factors are found to be inadequate system requirements engineering (with 22 root causes), inadequate project management (19 root causes), and missing or incomplete features (16 root causes). These findings can be of use to future researchers, policymakers, and practitioners seeking to identify methods of avoiding e-government IS failures, particularly in developing-world contexts.
\end{abstract}

\section{Keywords}

e-government, information systems (IS), project failure, literature review, qualitative meta-synthesis, design-reality gap analysis, ITPOSMO, root cause analysis

\section{Acknowledgement}

Google partially supported this work through the Google Africa PhD Fellowship Program.

DOI: $\underline{\text { https://doi.org/10.23962/10539/32210 }}$ 


\section{Recommended citation}

Nyansiro, J. B., Mtebe, J. S., \& Kissaka, M. M. (2021). E-government information systems (IS) project failure in developing countries: Lessons from the literature. The African Journal of Information and Communication (AJIC), 28, 1-29. https://doi.org/10.23962/10539/32210

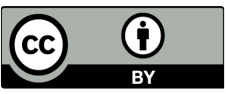

This article is licensed under a Creative Commons Attribution 4.0 International (CC BY 4.0) licence: https://creativecommons.org/licenses/by/4.0

\section{Introduction}

E-government information systems (IS) are increasingly becoming essential tools for the delivery of government services and the improvement of government administration in developing-world countries. Such systems enable citizens to access government services at a relatively low cost compared to traditional face-to-face services, making government services more convenient and accessible (Gilbert et al., 2004). These systems also transform the relationships between governments and their citizens by reducing citizens' personal interactions with government staff, thus increasing transparency and reducing corruption (Sun et al., 2015).

In Tanzania, notable e-government systems include the electronic payment gateway (GePG), which facilitates the collection of government revenues electronically from various sources, while simplifying the way citizens pay government bills (i.e., making payments through mobile phones and banks). Similarly, the traffic management system (TMS) facilitates the payment of drivers' fines by electronic means. The Ministry of Lands Information System (MOLIS) enables citizens to perform self-assessments of land rent and accrued penalties due to delayed payment, to generate bills, and to pay through the GePG. The system has helped to avoid multiple allocations of plots and minimise citizens' complaints about plot allocations. Other notable information systems include the national payment system (NPS), the electronic clearing house $(\mathrm{ECH})$, the integrated financial management system (IFMS), the integrated human resource and payroll system, and the retail payment system (RPS) (Ministry of Works, Transport and Communication, 2016; Sæbø, 2012).

However, many e-government projects in Tanzania, as in other developing countries, have experienced challenges leading to total or partial failure (Gunawong \& Gao, 2017). For example, Tanzania's Mwananchi portal-launched in 2009, revamped in 2014, and designed to act as the main information gateway between citizens and the government-was abandoned. And an e-claims system, acquired by the National Health Insurance Fund (NHIF) of Tanzania to facilitate the processing of insurance claims by health service providers, was delivered and accepted with critical features missing. As a result, some of the essential claim processing steps, including data 
exchange between subsystems, were performed manually. The system was prone to errors, labour-intensive, and took a long time to process claims (National Audit Office of Tanzania, 2019). Another project had to be initiated to fix the identified problems.

In Lesotho, an evaluation of four e-government websites revealed that they were missing critical features and functionalities in terms of accessibility, usability, transparency, and interactivity (Thakur \& Singh, 2012). In South Africa, the eThekwini Municipality's Revenue Management System (RMS) project, initiated in 2003, was only completed in 2016 and had a budget overrun of 666\% (Comins, 2020; Thakur \& Singh, 2012).

In an effort to better understand the main causes of e-government IS project failures in developing-world contexts, we conducted a literature review that applied qualitative meta-synthesis, design-reality gap analysis, and root cause analysis.

\section{Research design}

\section{Analytical frameworks}

\section{Qualitative meta-synthesis}

Qualitative meta-synthesis is a research method that involves the collection, interpretation, translation, and synthesis of findings across multiple qualitative studies (Sandelowski et al., 1997). The authors selected this method because most studies on e-government project failure are qualitative. This method is suitable for studies that require the integration of results from multiple qualitative studies as it combines both literature review and critical interpretation.

\section{Design-reality gap analysis}

In influential working papers on e-government for development, Heeks (2003; 2001) posits that most e-government project failures are the result of "design-reality gaps". Heeks $(2003 ; 2001)$ proposes seven dimensions that must be analysed in order to understand these gaps, using the acronym "ITPOSMO" to represent the seven dimensions, as follows:

- information;

- technology;

- processes;

- objectives and values;

- staffing and skills;

- management systems and structures; and

- other resources: time and money (Heeks, 2003, p. 3). 


\section{Root cause analysis}

Root cause analysis seeks to understand what happened and why it happened (Livingston et al., 2001). Al-Ahmad et al. (2009) use root cause analysis to review the literature on information technology (IT) project failures, finding that root causes fall under six factors: project management, top management, technology, organisational, complexity, and processes. Dalal and Chhillar (2013) conducted an empirical study to determine the root causes of software failures. According to Dalal and Chhillar (2013), the primary cause of software failure was inadequate testing due to insufficient testing tools, insufficient test cases, and lack of negative testing. Other root causes were inadequate project planning, requirement engineering, and design.

\section{Methodology}

\section{Data collection}

We performed multiple rounds of searches through different libraries, including Google Scholar, ACM Digital Library, Research Gate, IEEE Xplore, Springer, and Science Direct. The following keywords were used: e-government project failure; a case study of e-government project failure; causes of e-government project failure; factors leading to e-government project failure; the success of e-government projects; barriers of e-government systems; challenges of e-government projects; and issues of e-government projects. A total of 86 studies were found, and 64 articles were selected to be used in this study. The chosen studies were academic research articles and industrials research reports with a primary focus on the failure or success of e-government IS projects.

\section{Causal factor charting}

We used qualitative meta-synthesis to identify, across the 64 pieces of literature, the main causal factors that have been found to be responsible for IS project failure. Eighteen causal factors were identified. Additional literature searching was conducted to locate articles focusing on the identified causal factors and their root cause. A number of additional articles were identified, covering the following themes: user involvement (2 articles), e-government project management (6), e-government architecture (2), technology complexity (4), software testing (2), e-government infrastructure (3), information (2), requirement engineering (5), business processes management in governments (5), change management (2), management structure (2), e-government skills (2), top management involvement (1), and e-government systems integration (1).

\section{Root cause identification}

Fishbone diagrams were used to visualise the identified root causes linked to each of the 18 causal factors. The seven ITPOSMO design-reality gap dimensions served as root cause categories for each causal factor, drawn as branches connected to the 
backbone (the causal factor). The root causes identified in the literature were then mapped onto each of the seven root cause categories, as illustrated in Figure 1.

\section{Figure 1: Fishbone diagram with seven root cause categories (ITPOSMO dimensions)}

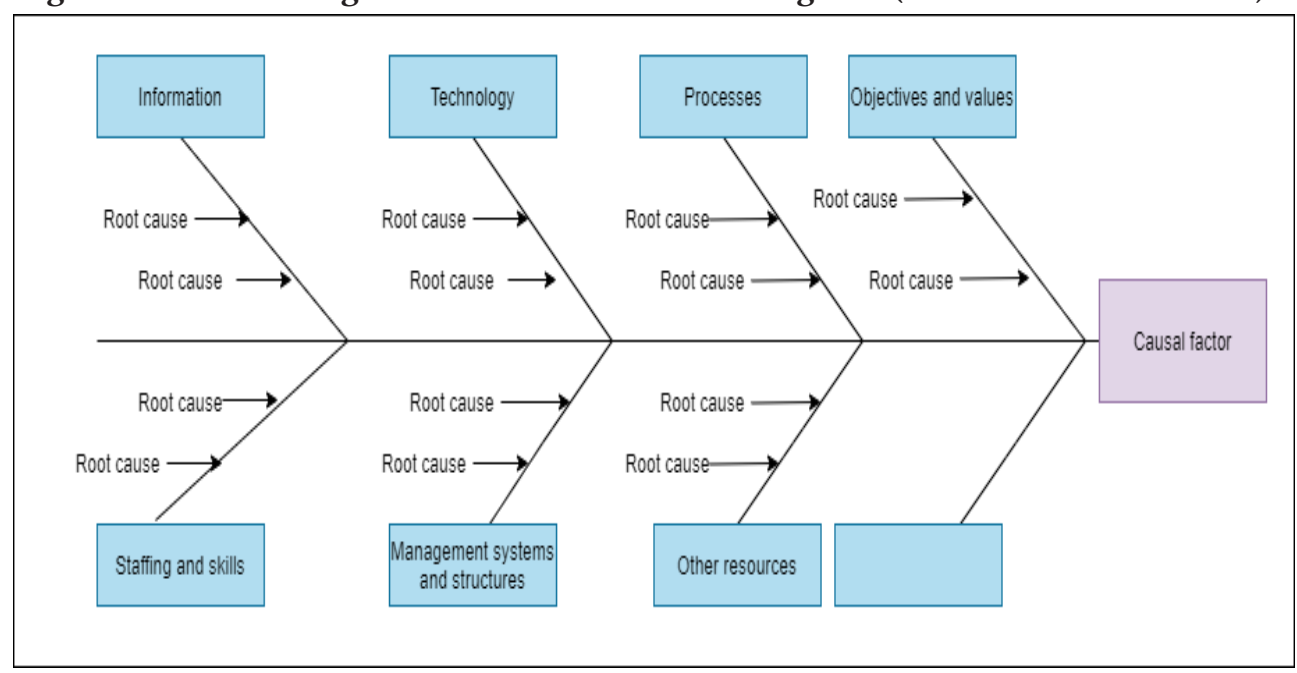

\section{Findings}

A total of 18 causal factors were identified in the literature via qualitative meta-synthesis, as shown in Table 1.

Table 1: Causal factors identified in existing literature

\begin{tabular}{|c|c|c|}
\hline & Causal factor & Literature \\
\hline 1 & $\begin{array}{l}\text { Inadequate system } \\
\text { requirements } \\
\text { engineering }\end{array}$ & $\begin{array}{c}\text { Baguma \& Lubega (2013), Goedeke et al. (2017), Hussain, } \\
\text { Mkpojiogu, \& Abdullah, (2016), Sweis (2015), Hofmann \& } \\
\text { Lehner (2001), Bubenko (1995), Michael \& Boniface (2014), } \\
\text { Zakaria et al. (2011) }\end{array}$ \\
\hline 2 & $\begin{array}{l}\text { Inadequate project } \\
\text { management }\end{array}$ & $\begin{array}{l}\text { Afyonluoğlu et al. (2014), Aikins (2012), Baguma \& Lubega } \\
\text { (2013), Goedeke et al. (2017), Gunawong \& Gao (2017), Hossan } \\
\text { et al. (2006), Imran et al. (2017), Rajapakse et al. (2012), Rajala } \\
\text { \& Aaltonen (2020), Sweis (2015), S. R. A. Shah et al. (2011), } \\
\text { Twizeyimana et al. (2018) }\end{array}$ \\
\hline 3 & $\begin{array}{c}\text { Missing or } \\
\text { incomplete features }\end{array}$ & $\begin{array}{c}\text { Baguma \& Lubega (2013), Damoah \& Akwei (2017), Goedeke et } \\
\text { al. (2017), Gunawong \& Gao (2017) }\end{array}$ \\
\hline 4 & $\begin{array}{l}\text { Inadequate project } \\
\text { planning }\end{array}$ & $\begin{array}{c}\text { Aikins (2012), Baguma \& Lubega (2013), Bakunzibake et al. } \\
\text { (2018), Ghapanchi \& Albadvi (2008), Goedeke et al. (2017), } \\
\text { Hossan et al. (2006), Rajala \& Aaltonen (2020), Rajapakse et al. } \\
\text { (2012), Twizeyimana et al. (2018) }\end{array}$ \\
\hline 5 & $\begin{array}{l}\text { Inappropriate choice } \\
\text { of technology }\end{array}$ & Goedeke et al. (2017), Ghapanchi \& Albadvi (2008), Lau (2003) \\
\hline 6 & $\begin{array}{c}\text { Insufficient top } \\
\text { management support }\end{array}$ & $\begin{array}{c}\text { Aikins (2012), Baguma \& Lubega (2013), Bakunzibake et al. } \\
\text { (2018), Goedeke et al. (2017), Ojha \& Pandey (2017), Sweis (2015) }\end{array}$ \\
\hline
\end{tabular}




\begin{tabular}{|c|c|c|}
\hline & Causal factor & Literature \\
\hline 7 & Integration failure & $\begin{array}{l}\text { Al-Khanjari et al. (2014), Ghapanchi \& Albadvi (2008), Goedeke } \\
\text { et al. (2017), Lam (2005) }\end{array}$ \\
\hline 8 & $\begin{array}{l}\text { Procurement and } \\
\text { contract shortcomings }\end{array}$ & $\begin{array}{l}\text { Goedeke et al. (2017), Ojha \& Pandey (2017), Rajapakse et al. } \\
\text { (2012) }\end{array}$ \\
\hline 9 & $\begin{array}{l}\text { Inadequate business } \\
\text { process management } \\
(\mathrm{BPM})\end{array}$ & $\begin{array}{l}\text { Afyonluoğlu et al. (2014), Baguma \& Lubega (2013), Bakunzibake } \\
\text { et al. (2018), Dada (2006), Goedeke et al. (2017), Gartlan \& } \\
\text { Shanks (2007), Martin \& Montagna (2006), Reffat (2003), Swartz } \\
\text { (2018), Trkman (2010) }\end{array}$ \\
\hline 10 & Insufficient IS testing & $\begin{array}{c}\text { Goedeke et al. (2017), Mansor \& Ndudi (2015), Rajala \& } \\
\text { Aaltonen (2020), Rajapakse et al. (2012) }\end{array}$ \\
\hline 11 & $\begin{array}{l}\text { Insufficient change } \\
\text { management }\end{array}$ & $\begin{array}{l}\text { Afyonluoğlu et al. (2014), Aikins (2012), Bakunzibake et al. (2018), } \\
\text { Ghapanchi \& Albadvi (2008), Dada (2006), Hossan et al. (2006), } \\
\text { Nograsek (2011) }\end{array}$ \\
\hline 12 & $\begin{array}{l}\text { Staffing and skills } \\
\text { shortfalls }\end{array}$ & $\begin{array}{l}\text { Abbas et al. (2017), Baguma \& Lubega (2013), Dada (2006), } \\
\text { Goedeke et al. (2017), Hossan et al. (2006), Rajala \& Aaltonen } \\
\text { (2020), Rajapakse et al. (2012), Ojha \& Pandey (2017), } \\
\text { Twizeyimana et al. (2018), Zakaria et al. (2011) }\end{array}$ \\
\hline 13 & $\begin{array}{l}\text { Technical over- } \\
\text { complexity }\end{array}$ & $\begin{array}{l}\text { Goedeke et al. (2017), Abbas et al. (2017), Botchkarev \& Finnigan } \\
\text { (2015), Sweis (2015), Lau (2003), Mukherjee (2008) }\end{array}$ \\
\hline 14 & Obsolete technology & Baguma \& Lubega (2013), Goedeke et al. (2017) \\
\hline 15 & Information gaps & Heeks (2001), Rajapakse et al. (2012), Vyas et al. (2014) \\
\hline 16 & $\begin{array}{l}\text { Inadequate } \\
\text { infrastructure }\end{array}$ & $\begin{array}{l}\text { Baguma \& Lubega (2013), Dahiya \& Mathew (2018), } \\
\text { Bakunzibake et al. (2018), Goedeke et al. (2017), Hossan et al. } \\
\text { (2006), Rahman et al. (2014), Twizeyimana et al. (2018) }\end{array}$ \\
\hline 17 & Political interference & $\begin{array}{c}\text { Abbas et al. (2017), Baguma \& Lubega (2013), Hossan et al. } \\
\text { (2006), Rajala \& Aaltonen (2020), Toots (2019) }\end{array}$ \\
\hline 18 & $\begin{array}{l}\text { Inappropriate } \\
\text { organisational } \\
\text { management } \\
\text { structure }\end{array}$ & $\begin{array}{c}\text { Abbas et al. (2017), Goedeke et al. (2017), Rajala \& Aaltonen } \\
\text { (2020), S. R. A. Shah et al. (2011) }\end{array}$ \\
\hline
\end{tabular}

For each of the 18 causal factors tabulated above, root causes were identified in the literature, and mapped onto fishbone diagrams. The 18 sub-sections that follow explain each of the causal factors and provide a fishbone diagram for each causal factor's root causes.

\section{Inadequate system requirements engineering}

Requirements engineering is the process of discovering, documenting, and analysing services to be offered by a given system and the constraints under which those services should be provided (Feldgen \& Clua, 2014). It involves systematic investigation and studying existing systems, processes, materials, operating environments, users' needs, and other artefacts to establish the new system's needs (Ullah et al., 2011). Bail (2010) estimated that inadequate system requirements specifications caused $50 \%$ of 
IS project failures. For instance, the student information system implemented by the Uganda Management Institute (UMI) failed because it missed vital features in the finance module. The analyst failed to include these features' requirements in the initial requirements specification document (Baguma \& Lubega, 2013). Requirements engineering problems include missing requirements, incomplete requirements, ambiguous requirements, poor requirement traceability, elicitation of irrelevant requirements, and poor requirements management (Shah \& Patel, 2014). The root causes of inadequate information system requirements engineering are presented in Figure 2.

Figure 2: Inadequate system requirements engineering

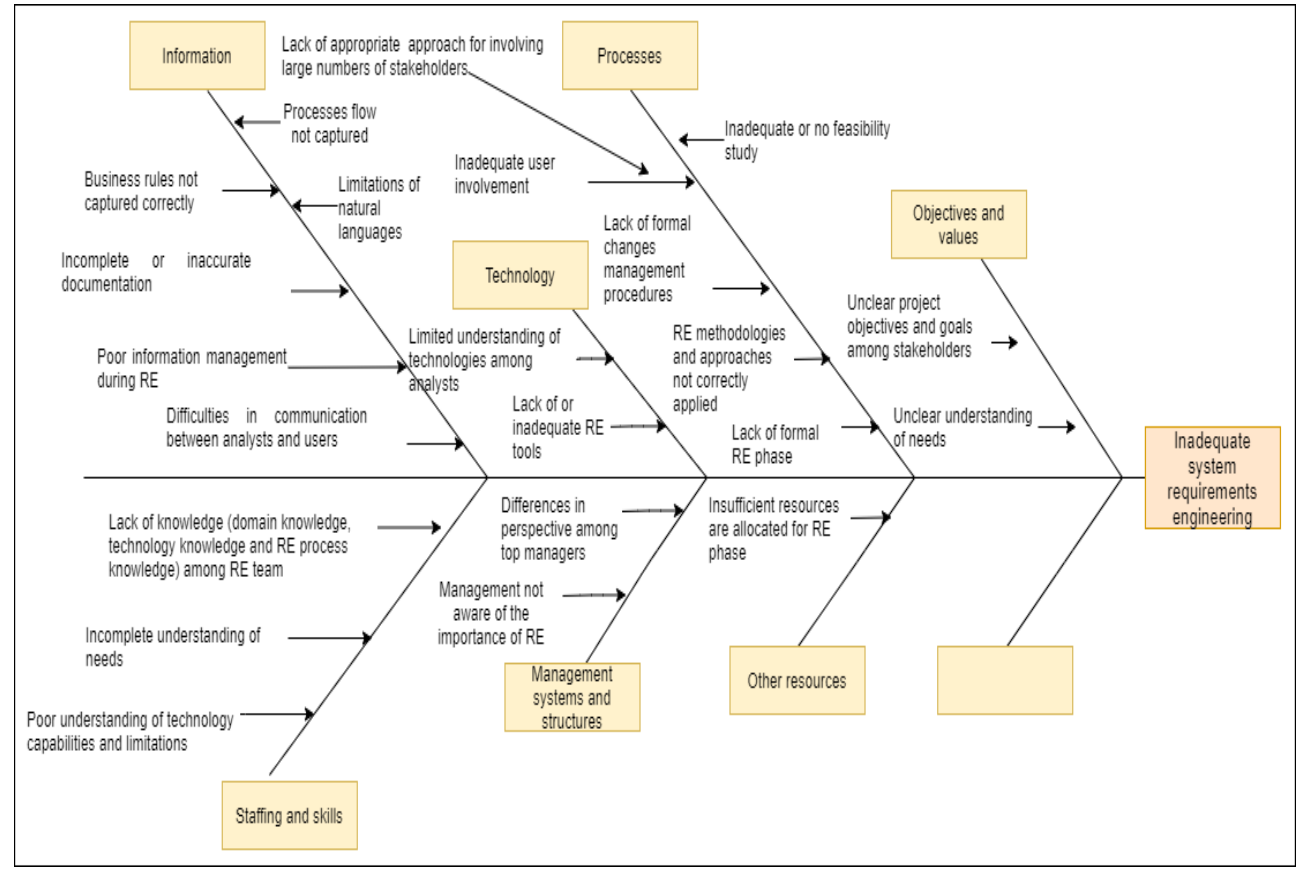

\section{Inadequate project management}

Project management is the application of knowledge, skills, tools, and techniques to guide the project activities in accordance with project objectives and goals (Imran et al., 2017). Many e-government IS projects fail due to inadequate project management. The electronic National Traffic Information System (e-NaTIS) in 
South Africa failed mainly due to poor project management (Rajapakse et al., 2012). E-government projects should adopt proven project management methodologies, align their goals with organisational strategic goals, and hire competent people to manage them (Aikins, 2012). The root causes of inadequate project management are shown in Figure 3.

Figure 3: Inadequate project management

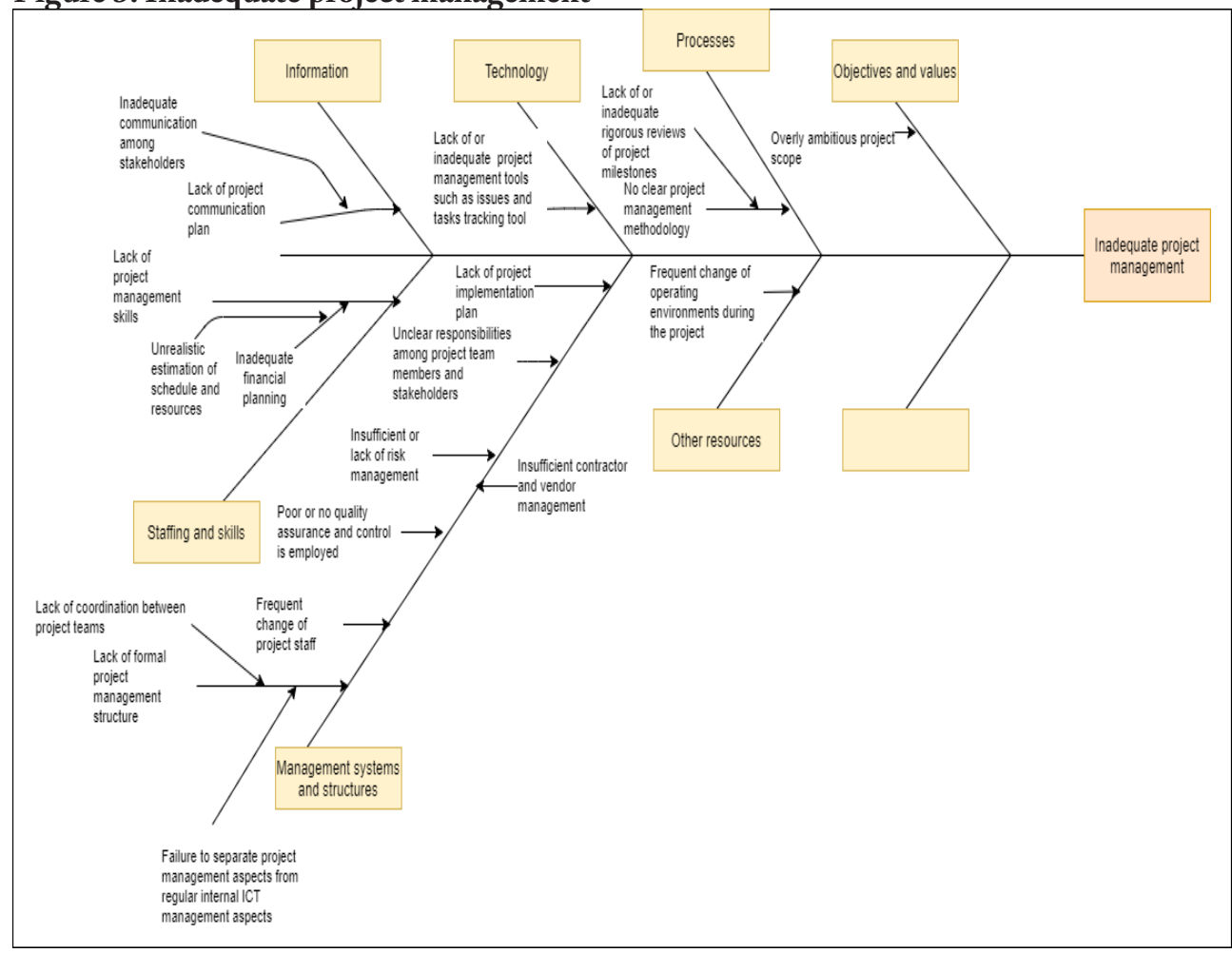

\section{Missing or incomplete features}

An IS project is said to be successful if it is delivered within time, budget, and with desired quality, features, and usability that reflects the real needs of the customers or users (Hussain, Mkpojiogu, \& Abdullah, 2016). In some cases, e-government IS 
projects are delivered and accepted with missing or incomplete vital features, thus failing to function and provide the anticipated results (Baguma \& Lubega,2013; Damoah \& Akwei, 2017). This practice leads to a total or partial failure of the e-government IS project. For example, the Friend a Gorilla project in Uganda, implemented to raise awareness and funds for promoting Gorilla conservation, was delivered without crucial features for the online selling of promotional materials and SMS-based Gorilla friending (Baguma \& Lubega, 2013). Several root causes can lead to the delivery of incomplete projects, including government officials' compromises due to corruption, and the failure to follow the correct procedures (Damoah \& Akwei, 2017). Other root causes are as indicated in Figure 4.

\section{Figure 4: Missing or incomplete features}

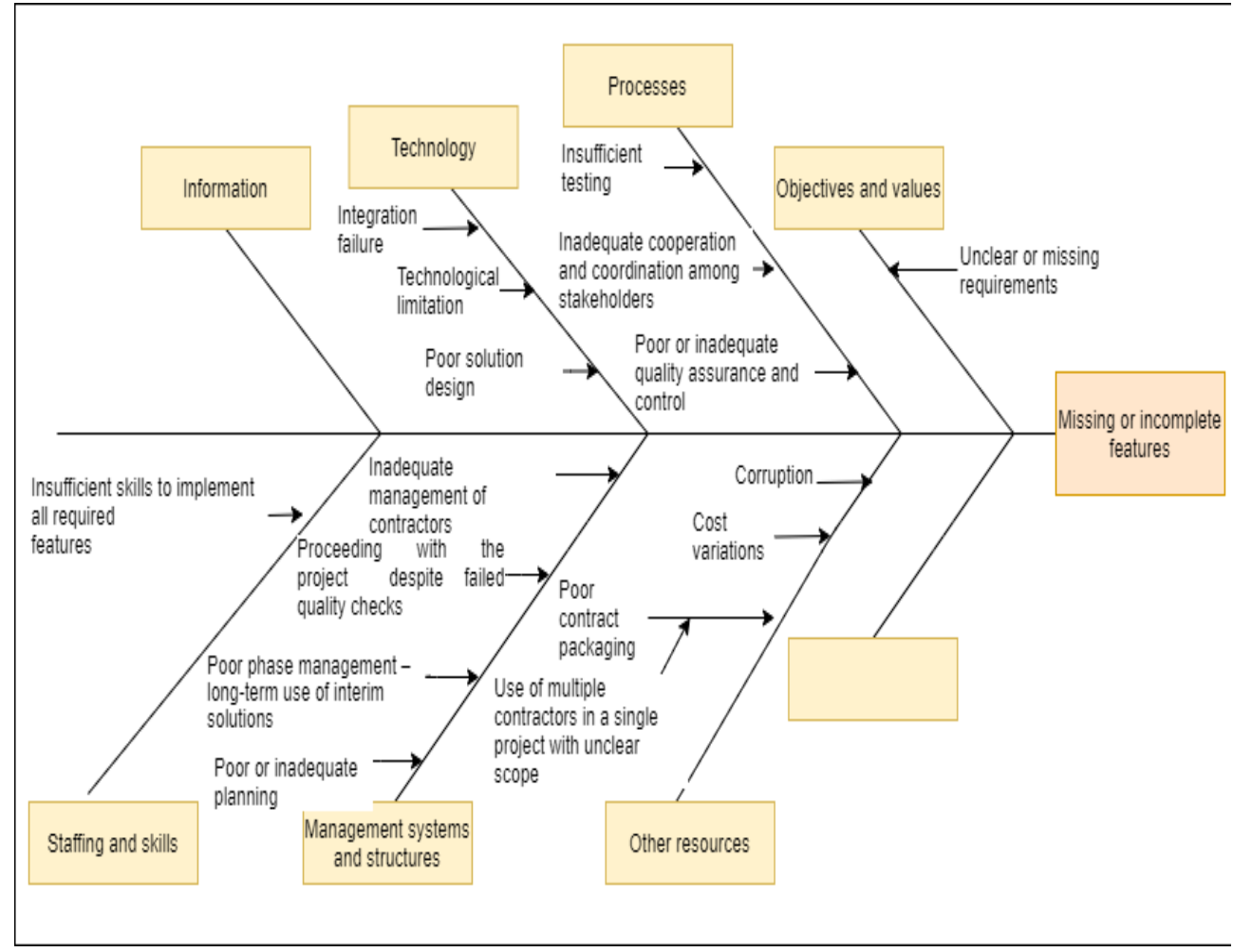




\section{Inadequate project planning}

The project plan outlines activities, timelines, resources, risks, constraints, expected output, and baseline information against which the project can be conducted, monitored, and evaluated (Imran et al., 2017). Many of the challenges facing e-government projects can be avoided or minimised if projects are thoroughly planned (Ghapanchi \& Albadvi, 2008). The e-Revenue License project in Sri-Lanka is considered a successful e-government initiative because it was adequately planned (Rajapakse et al., 2012). The root causes of inadequate project planning are shown in Figure 5.

\section{Figure 5: Inadequate project planning}

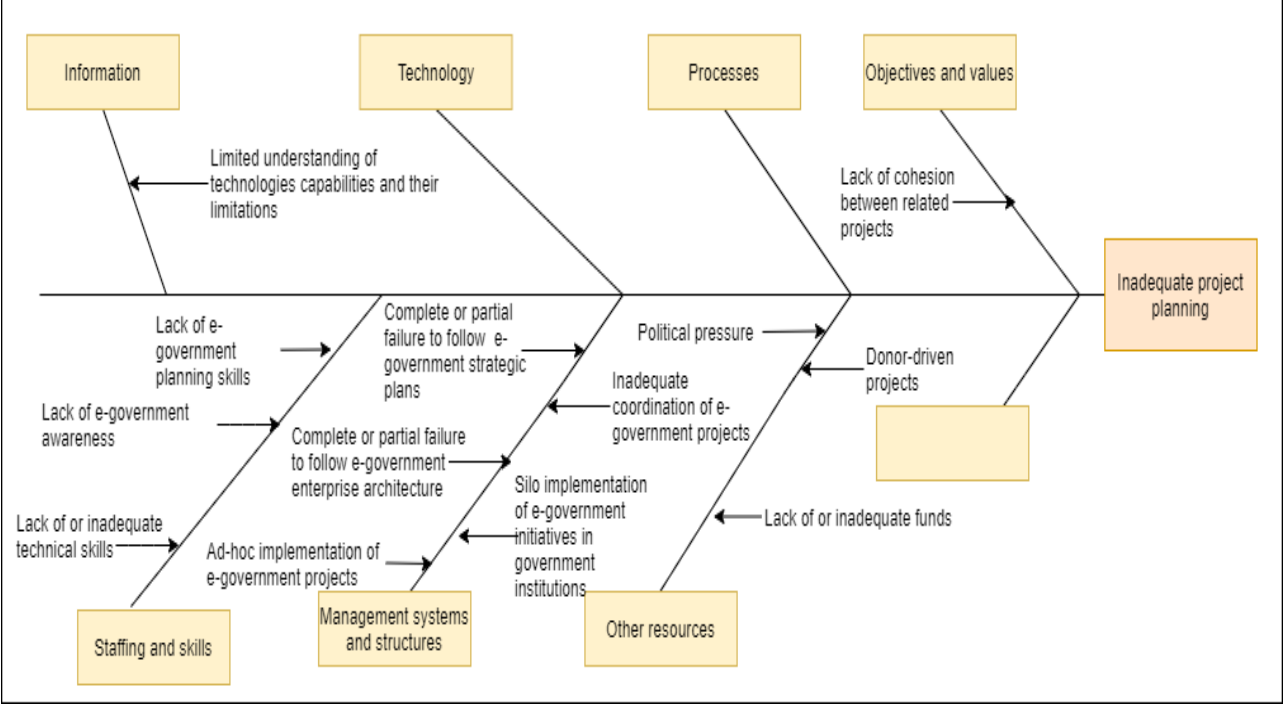

\section{Inappropriate choice of technology}

When selecting technology for a particular project, several factors must be considered, including easy to learn and use, fit for the purpose, easy to integrate with existing systems, availability of documentation and support, availability of skills, overall implementation costs, overall perceived quality, and usefulness (Hussein et al., 2007). Factors such as vendor hype and corruption may influence the choice of technology, leading to what is commonly known as vendor-driven projects (Damoah \& Akwei, 2017). Thailand's smart card project, as described by Gunawong and Gao (2017), is an example of the use of inappropriate technology in an e-government initiative. 
This project, which was launched in 2003 and abandoned in 2006, produced smart cards that could not be used electronically. Governments are advised to thoroughly evaluate the technologies before contracting suppliers (Lau, 2003). The root causes of inappropriate choice of technology are shown in Figure 6.

\section{Figure 6: Inappropriate choice of technology}

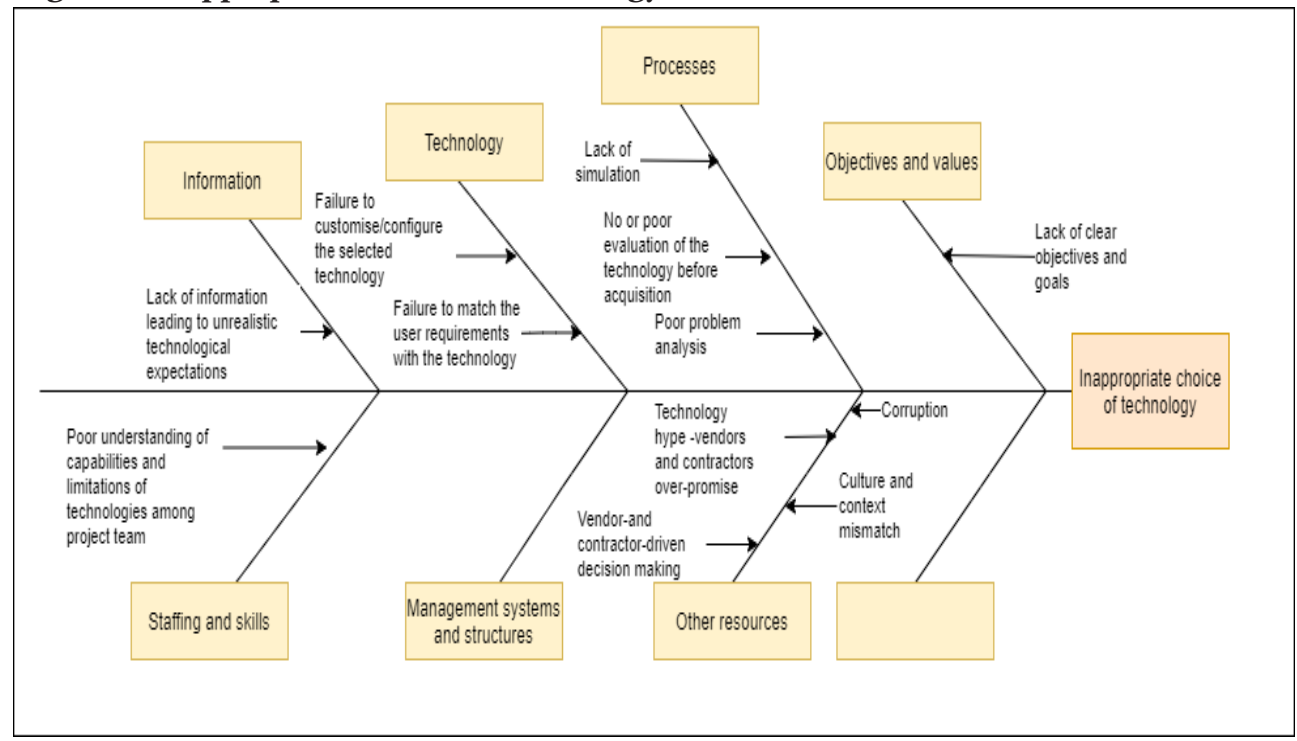

\section{Insufficient top management support}

As owners and sponsors of the e-government IS project, top managers are expected to closely follow up on critical aspects of the project, including ensuring that the project goals, objectives, vision, and values reflect those of the organisation. Top managers have to ensure that the project is managed according to the organisation's standards and that resources are made available in a timely fashion. They also have to ensure that project risks are identified and adequately mitigated. A systematic review of the project will ensure that milestones are accomplished in a timely fashion and 
that project resources are appropriately used. Finally, top managers must promote the project to internal and external stakeholders (Ojha \& Pandey, 2017; Zwikael, 2014). The root causes of insufficient top management support are shown in Figure 7.

Figure 7: Insufficient top management support

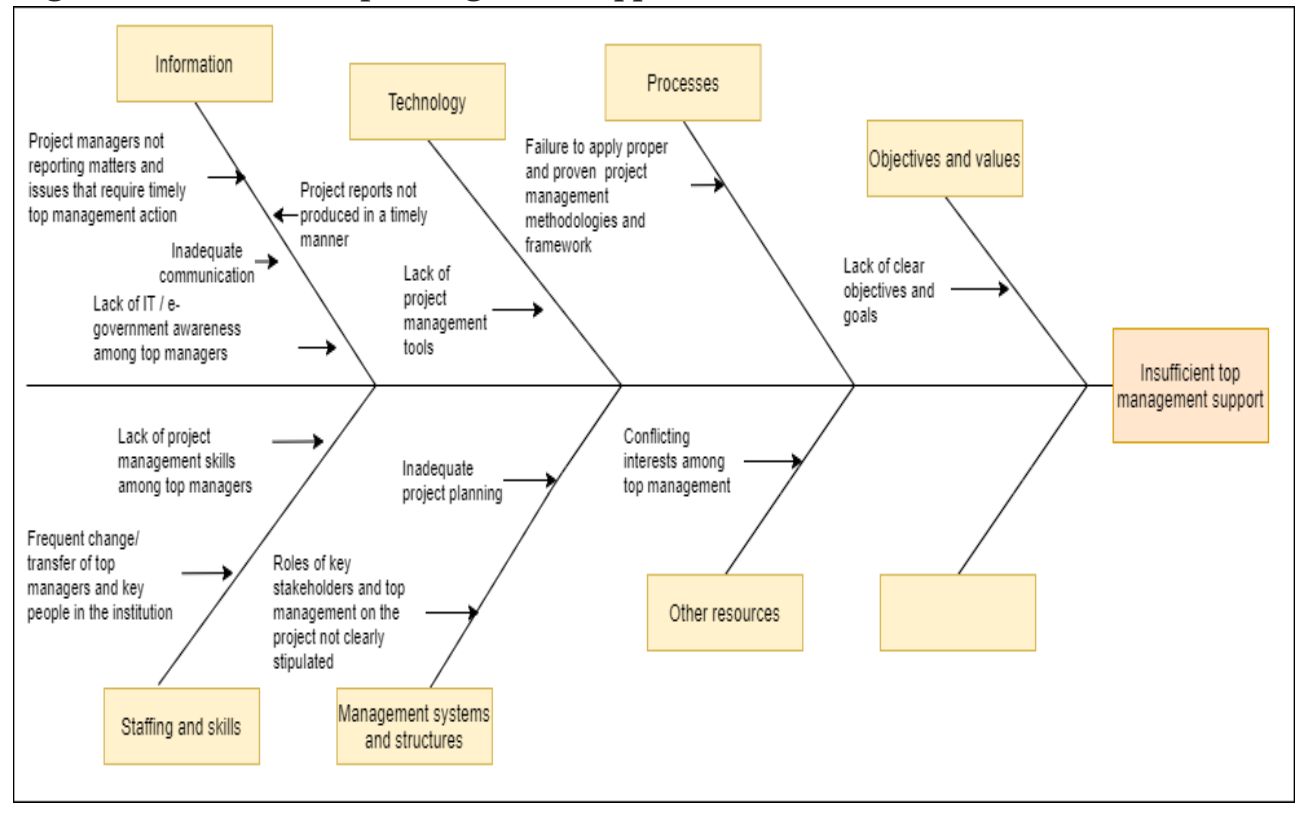

\section{Integration failure}

Delivering seamless services requires e-government systems to be integrated vertically and horizontally (Layne \& Lee, 2001). However, this has been difficult to achieve (Sun et al., 2015). According to Lam, W. (2005), e-government systems integration challenges are categorised into four main categories: strategy, technology, policy, and organisation. Most government institutions and agencies develop their e-government systems independent from one another without paying much attention to how other government institutions and agencies might interact with them (Al-Khanjari et al., 2014). For example, integration between the citizen help requests (CHR) system designed by Bangladesh Police to facilitate online incident reporting and an identification system to authenticate the requesters failed due to technology and 
organisational issues. Therefore, the police kept receiving requests with fake names, addresses, and contact information (Hasan, 2015). The root causes of integration failure are shown in Figure 8.

Figure 8: Integration failure

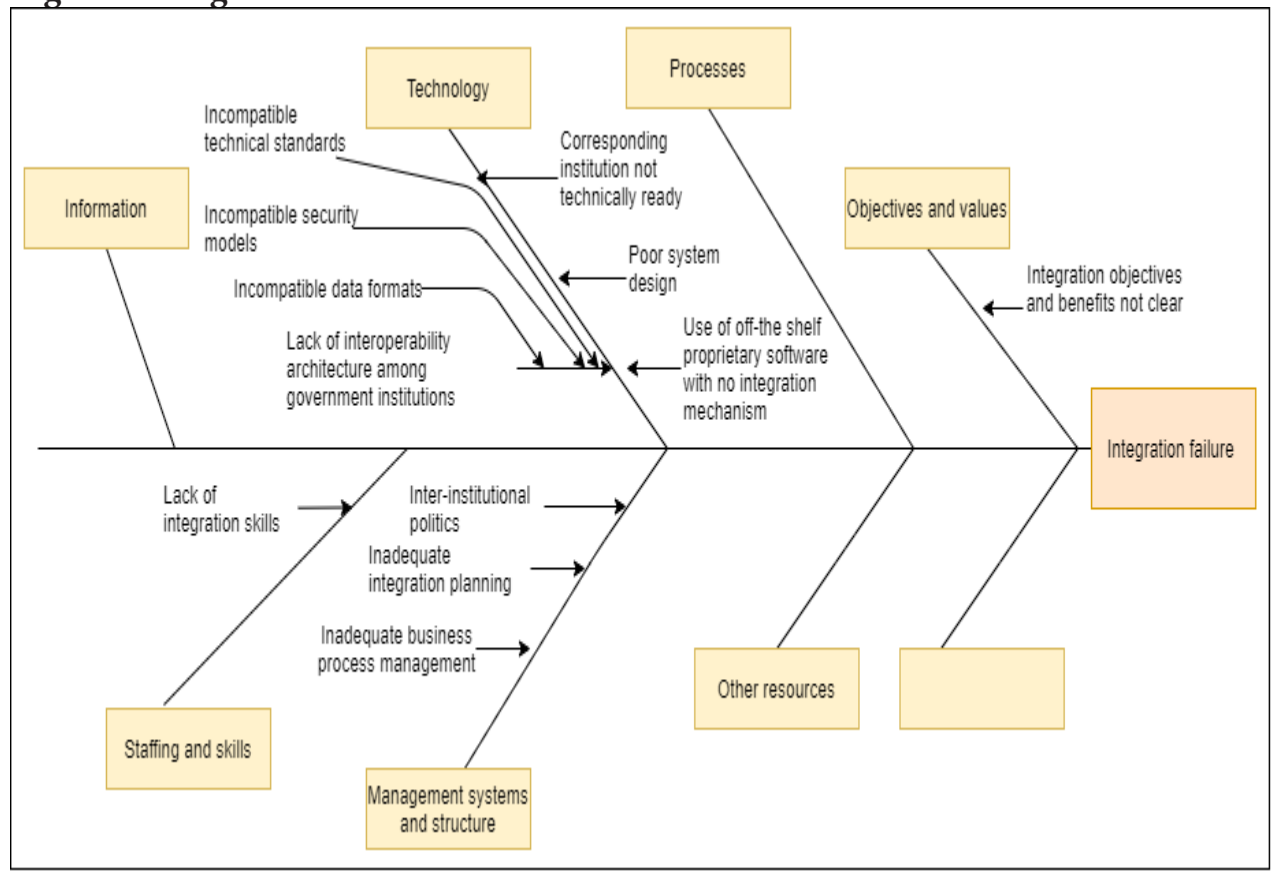

\section{Procurement and contract shortcomings}

Government institutions outsource most e-government IS projects to external vendors, contractors, and suppliers through legally binding contracts. Different forms of public-private partnerships are used in some cases (Ojha \& Pandey, 2017). In either situation, it is essential to have a contract that specifies the parties involved, their obligations, the consequences for failure to meet the obligations, and settlement procedures for disagreement (Afyonluoğlu et al., 2014). Failure to have a fair contract may lead to legal issues, which may eventually lead to project failure. Figure 9 presents the root causes of procurement and contract shortcomings. 
Figure 9: Procurement and contract shortcomings

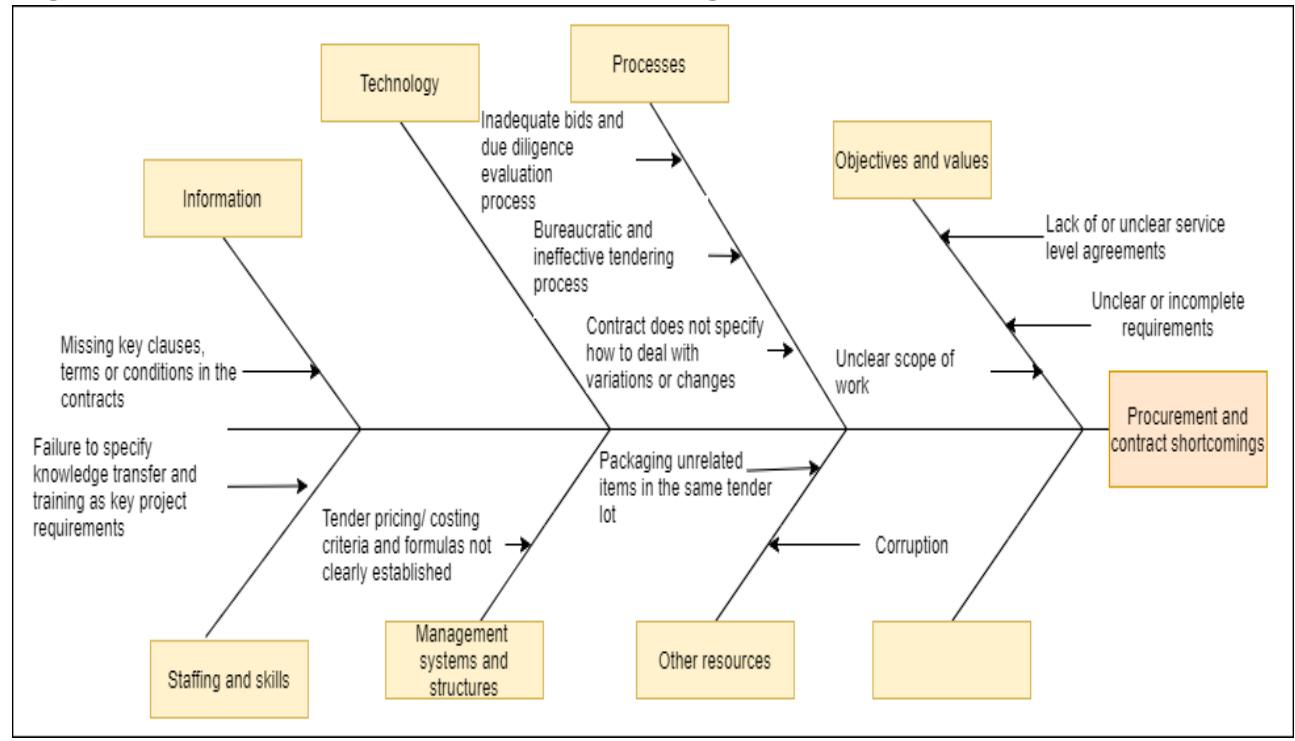

\section{Inadequate business process management (BPM)}

Business process management (BPM) is an organisational strategy to identify, model, analyse, measure, automate, optimise, and continually improve fundamental activities in an organisation (Trkman, 2010). The overall objective of e-government initiatives is to improve public service delivery and enhance administration processes through e-services. In this case, BPM and e-government are two initiatives that have to go together as they complement each other. Unfortunately, most e-government IS projects are designed without BPM as a significant component (Martin \& Montagna, 2006). Implementing an e-government information system without undertaking process re-engineering may lead to undesirable results and eventually project failure. The root causes of inadequate BPM are shown in Figure 10. 
Figure 10: Inadequate business process management (BPM)

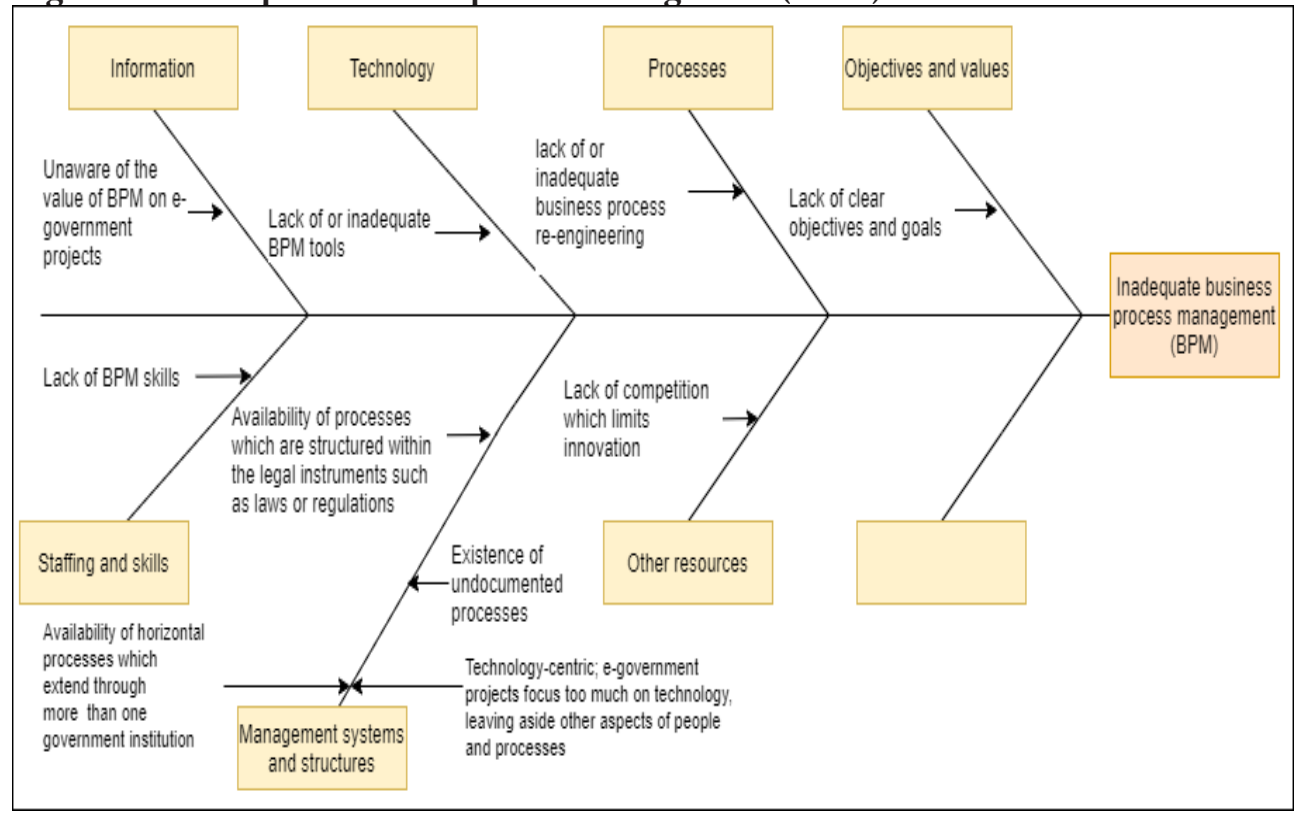

\section{Insufficient IS testing}

IS testing is one of the critical phases in the system development life cycle, aiming to verify, validate, detect, and fix errors in the system (Chaudhary, 2017). During the verification process, the developed system is checked to assess its conformity against the specified requirements. Insufficient system testing leads to the system's inability to meet stakeholders' expectations and needs, leading to abandonment (Mansor \& Ndudi, 2015). The root causes of insufficient IS testing are shown in Figure 11. 


\section{Figure 11: Insufficient IS testing}

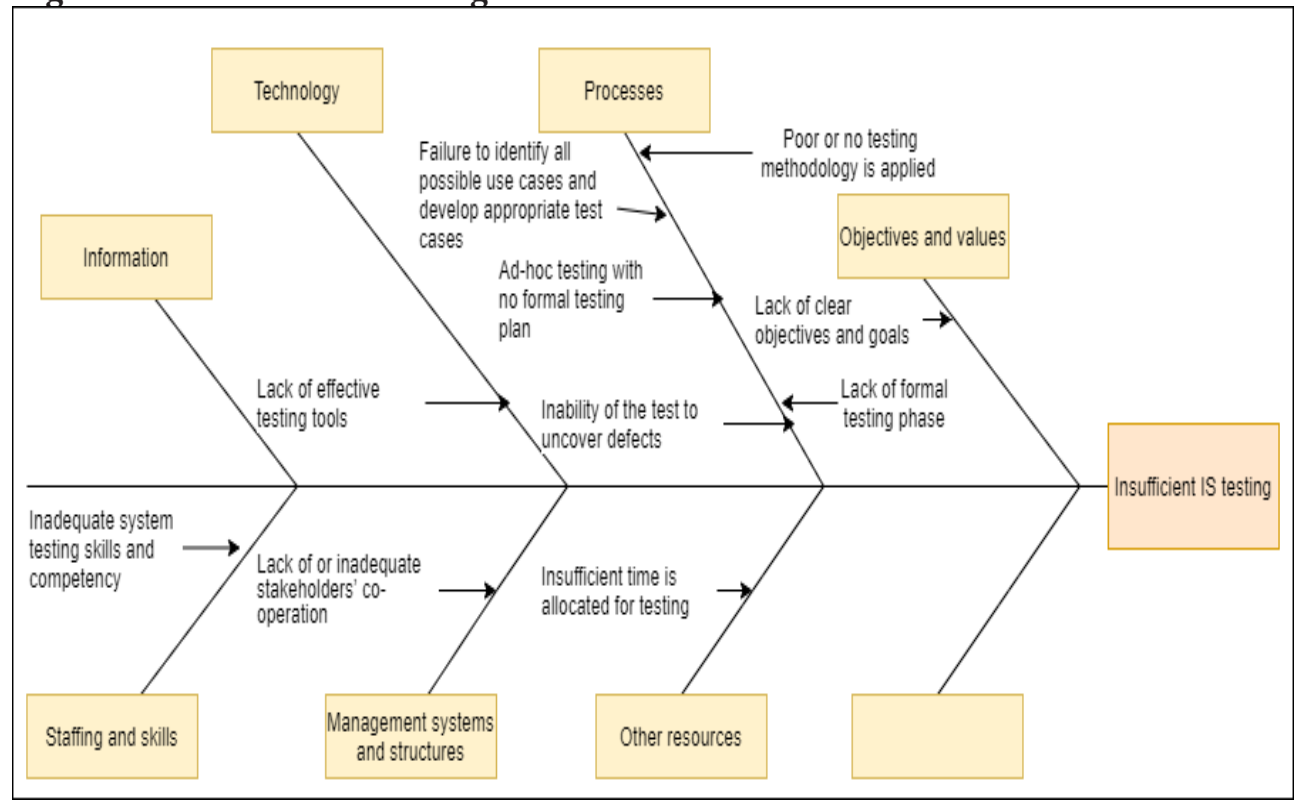

\section{Insufficient change management}

E-government projects are transformational as they tend to change the business process, service delivery mechanisms, and organisational structure (Afyonluoğlu et al., 2014). Successful transformation requires an appropriate change management process. Some e-government systems projects fail due to the institution's inability to make the necessary institutional rearrangements to shift from the old processes to the new processes offered by the developed e-government IS. A practical change management framework to support the successful implementation of the e-government system project must consider all the organisation's aspects, including technology, administration, operation, legislation, people, and organisation (Afyonluoğlu et al., 2014; Nograsek, 2011). The root causes of insufficient management are shown in Figure 12. 
Figure 12: Insufficient change management

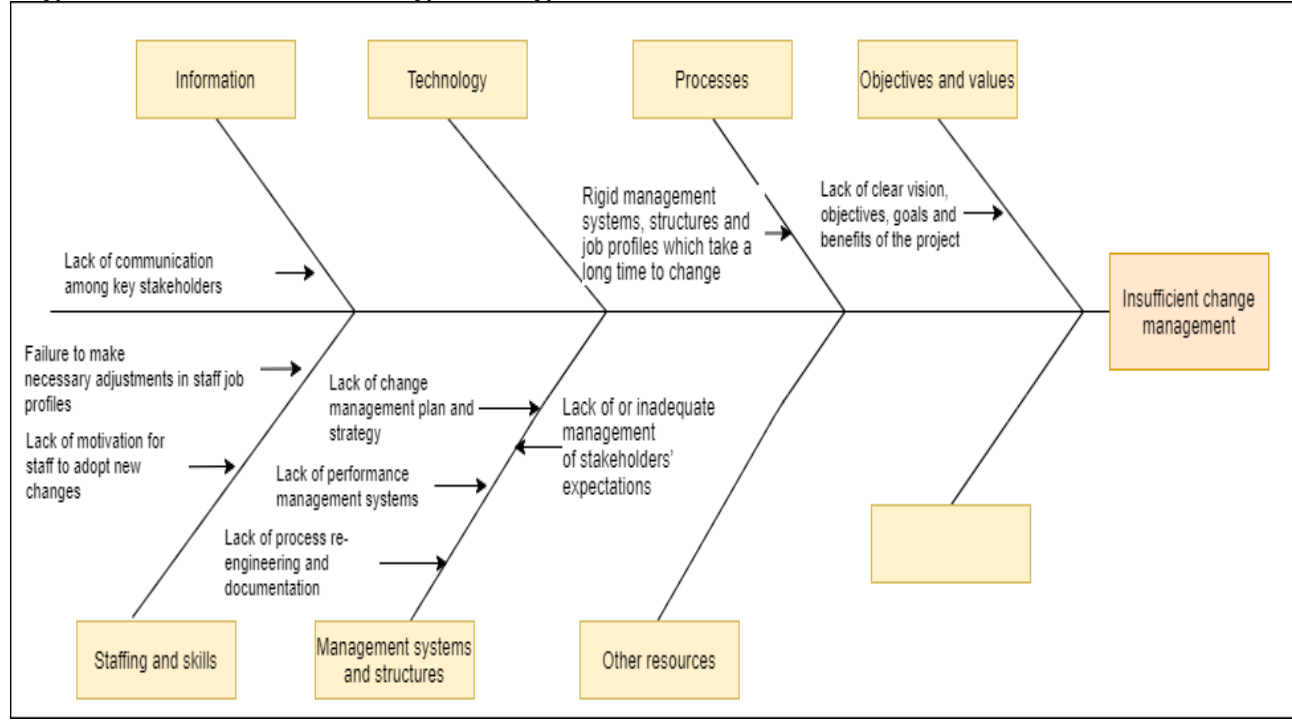

\section{Staffing and skills shortfalls}

An effective e-government project implementation team must possess essential skills, including: strategic information technology skills, information society skills, information management skills, technical skills, project management skills, and communication and presentation skills (Lau, 2003; Al Salmi et al., 2017). Most governments in developing countries suffer from a severe shortage of skilled staff (Rahman et al., 2014). The lack of relevant technical skills within the e-government project team negatively impacts the information systems quality (Ghapanchi \& Albadvi, 2008). Khan and Islamabad (2009) estimated that Pakistan's government is getting barely $40 \%$ of results from its investment in e-government initiatives due to the lack of a skilled workforce. The root causes of staffing and skills shortfalls are shown in Figure 13. 
Figure 13: Staffing and skills shortfalls

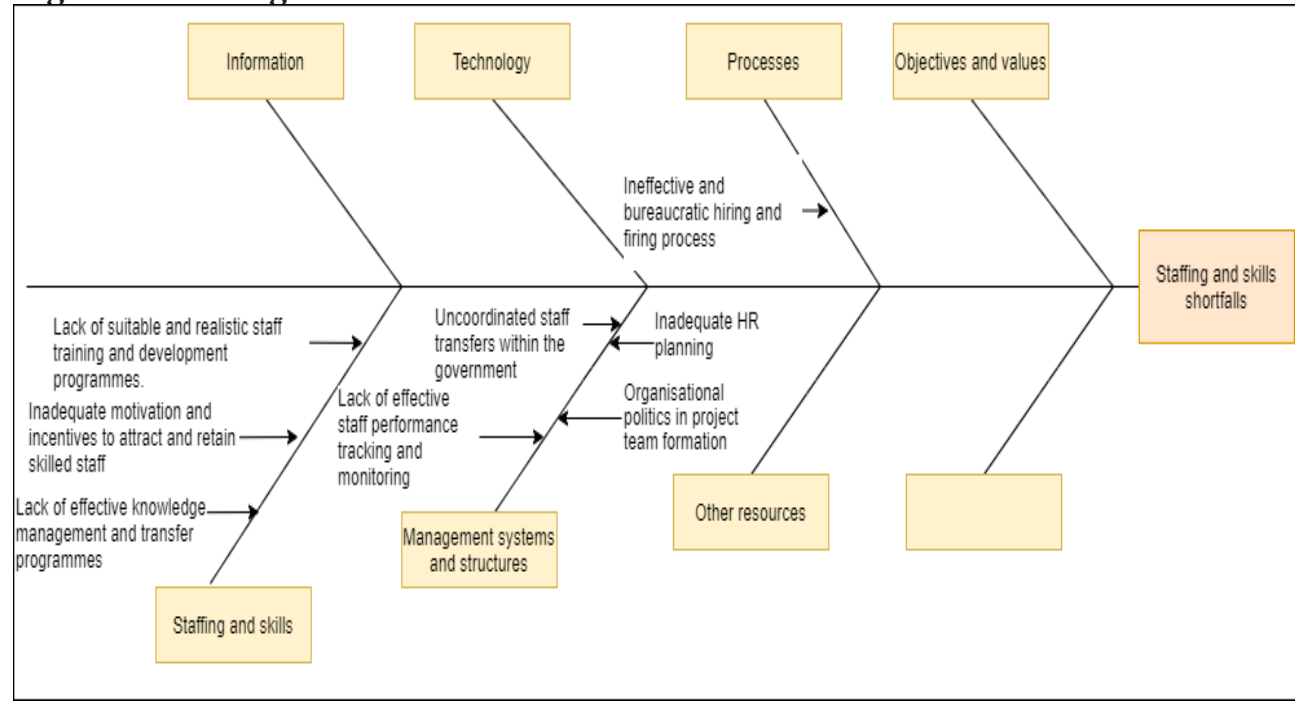

\section{Technical over-complexity}

In this context, technical complexity refers to the difficulty of solving a given problem using the technology in question. It includes the inability to precisely determine information and processing requirements, data communication, and the overall system design, setup, and configurations (Xia \& Lee, 2005). Lack of intensive technology evaluation is a leading cause of technical complexities and problems in e-government IS projects. Learning from previous project mistakes is crucial in mitigating risks and failures in new projects (Mukherjee, 2008). Figure 14 presents the root causes of technical over-complexity.

\section{Figure 14: Technical over-complexity}

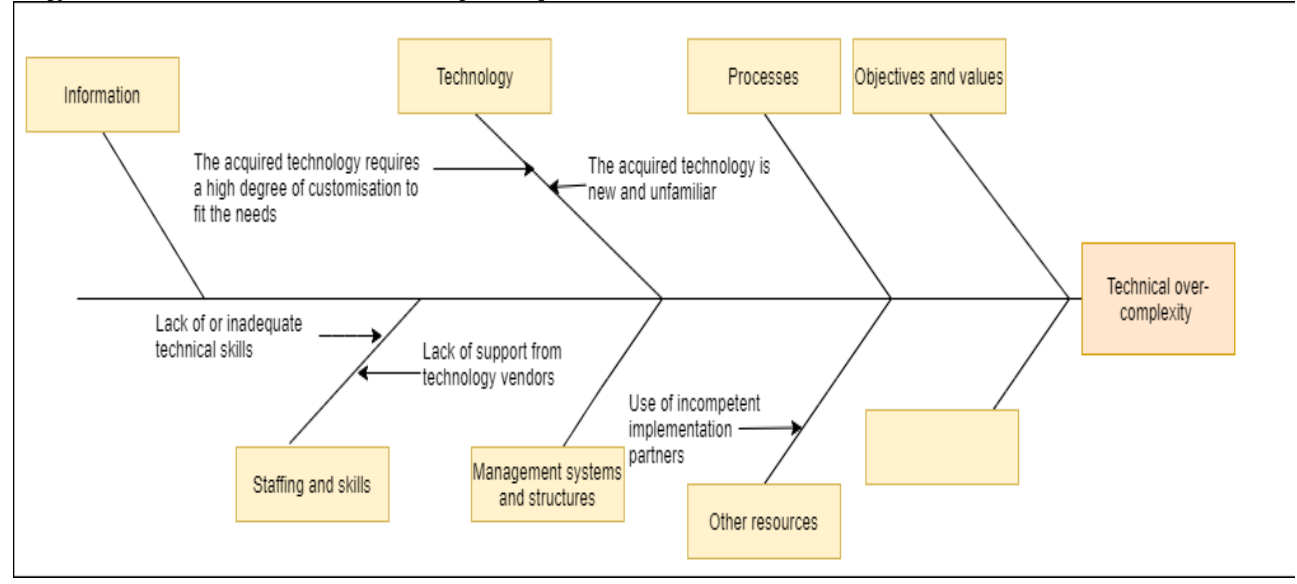




\section{Obsolete technology}

The planning and implementation of e-government systems projects take a relatively long period of time. Consequently, some e-government projects are delivered while their associated technologies are or are about to become obsolete. Developing countries also suffer from adopting outdated technology when technological equipment and systems are donated by developed countries. The root causes of obsolete technology are shown in Figure 15.

Figure 15: Obsolete technology

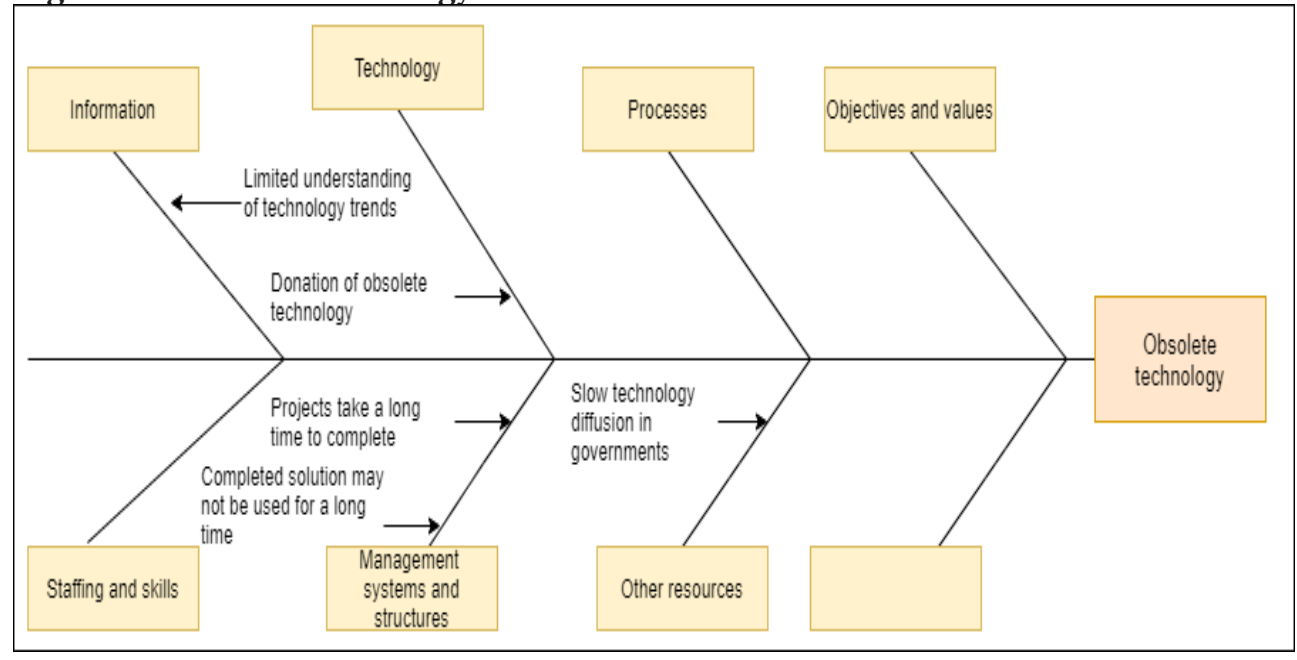

\section{Information gaps}

Mismatch of data between what is captured or produced by the system and what is required by users of the system can lead to e-government IS failure (Heeks, 2001). In e-government IS, the information gaps exist in three situations: capturing unnecessary information not required for processing or reporting; the failure to capture essential information necessary for processing or reporting; and asking for particular information that may not be available or relevant to some users or scenarios. For instance, the citizen help requests (CHR) system designed by Bangladesh Police required a request to have a valid signature of the requestor to start the investigation (Hasan, 2015). Citizens' inability to provide digital signatures online made the system unusable (Hasan, 2015). The root causes of information gaps are shown in Figure 16. 
Figure 16: Information gaps

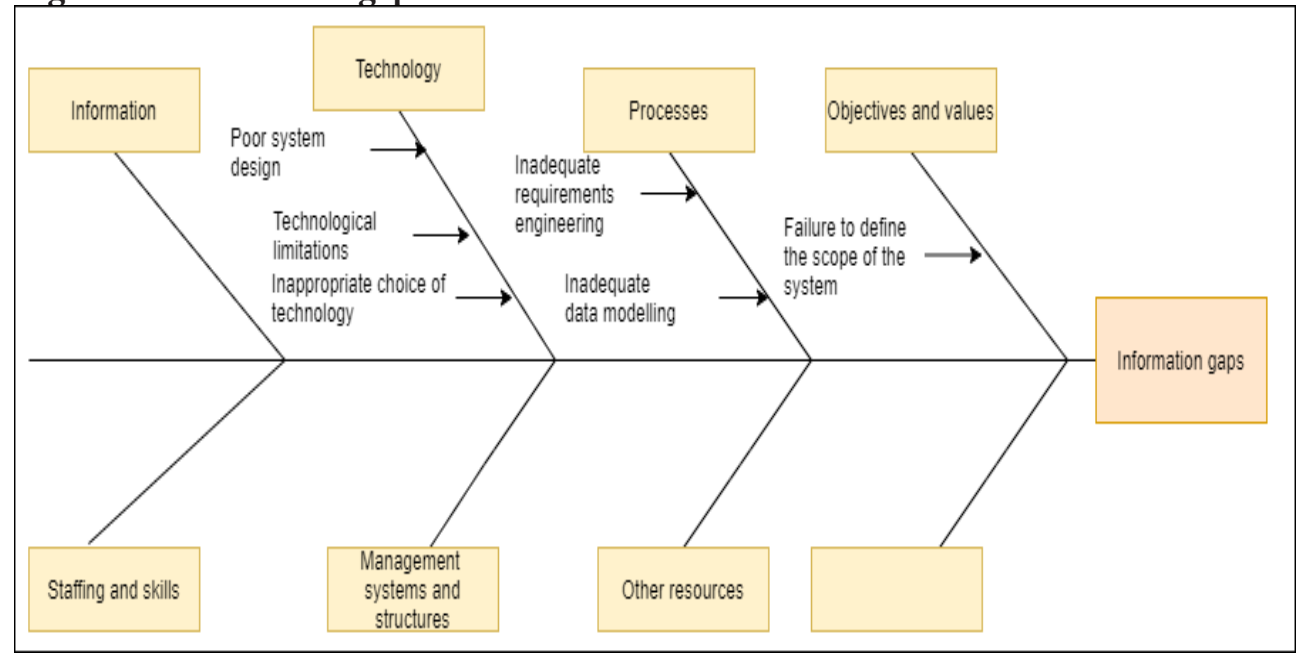

\section{Inadequate infrastructure}

E-government infrastructure encompasses hardware platforms, software platforms, middleware, data communications equipment, networks, backup hardware, disaster recovery hardware, and security technologies (Dahiya \& Mathew, 2018). These devices and equipment make it possible to offer e-government services that are accessible to users. In IT, the performance and effectiveness of infrastructure are measured with reference to: reliability - its ability to ensure continuous uptime; scalability - its ability to accommodate increased load; and flexibility - its ability to accommodate changes that may be required (Dahiya \& Mathew, 2018). The root causes of inadequate infrastructure are presented in Figure 17.

Figure 17: Inadequate infrastructure

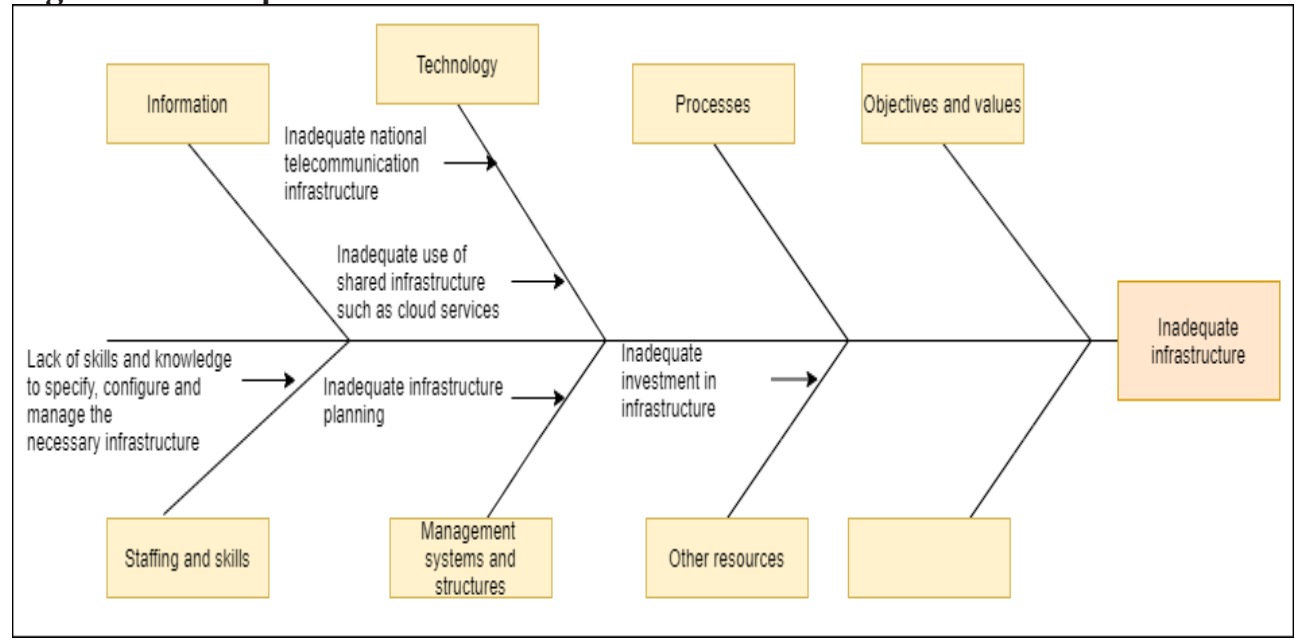




\section{Political interference}

Governments are run by politicians who influence many aspects of decision making, leadership, and development initiatives. Politicians influence many government projects in positive or negative ways through several means, such as appointing personnel responsible for projects, manipulating project scopes and deliverables to suit their political interests, and making various decisions (Baguma \& Lubega, 2013; Rajala \& Aaltonen, 2020). E-government IS projects may also similarly suffer or benefit from political interference. The root causes of political interference are shown in Figure 18.

Figure 18: Political interference

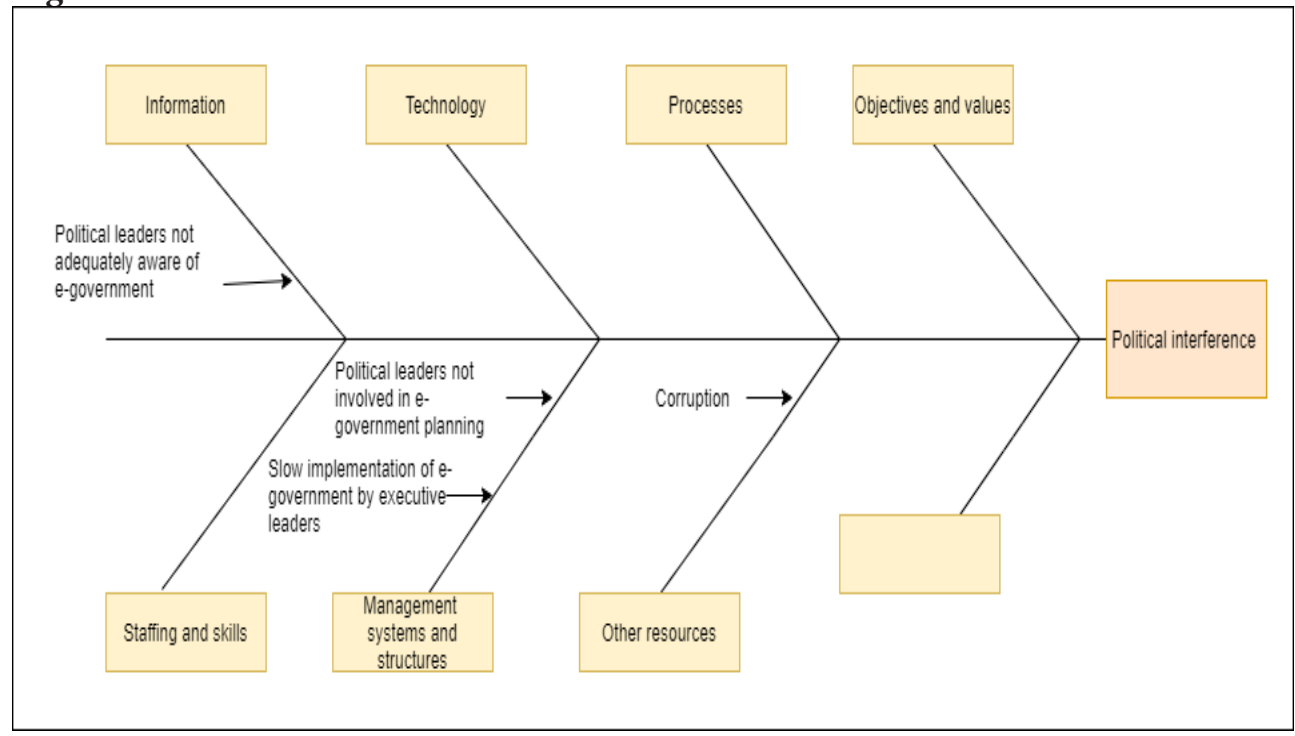

\section{Inappropriate organisational management structure}

Government institutions are structured to support their core mandates. They employ a hierarchical structure with bureaucratic leadership, tight relationships, and rigid rules and procedures (Matte, 2017). Organisational structure is a critical element of e-government governance. Organisations implementing e-government initiatives must undertake the necessary reforms to accommodate and manage the e-government system's changes. The root causes of inappropriate organisational management structure are shown in Figure 19. 
Figure 19: Inappropriate organisational management structure

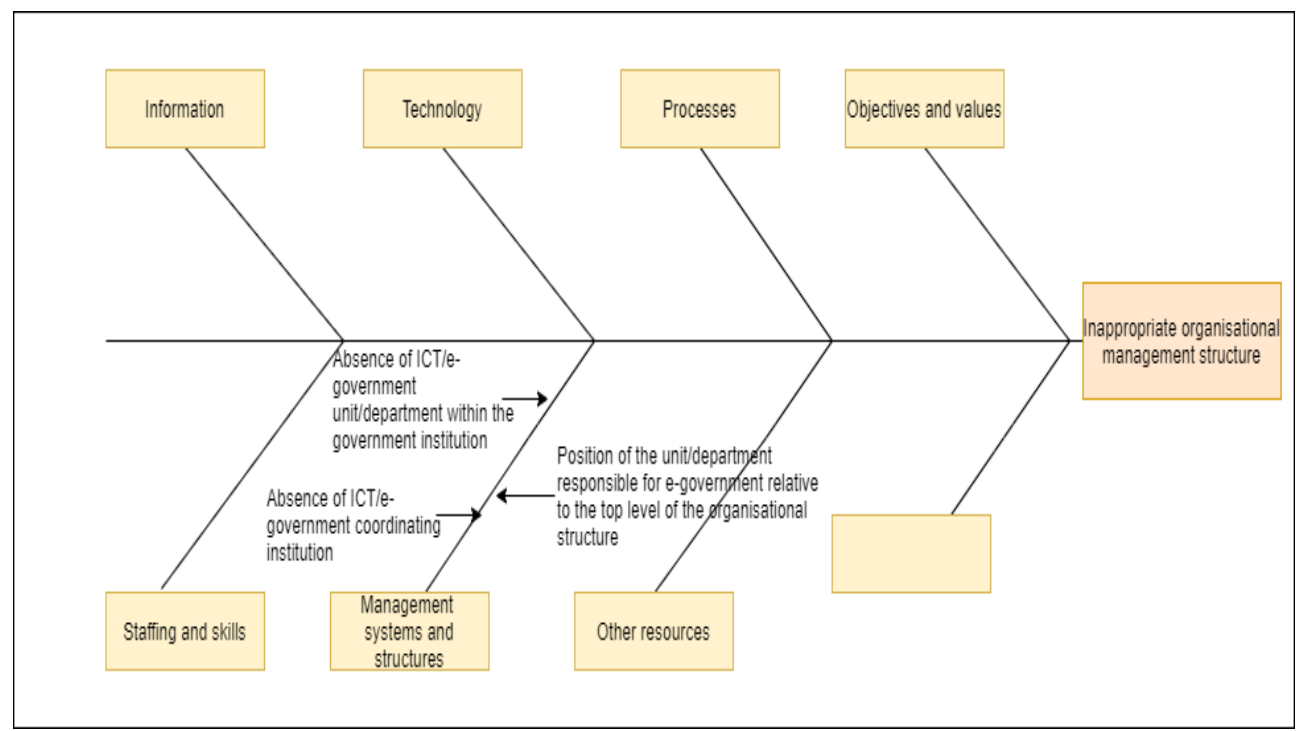

\section{Analysis and conclusions}

\section{Design-reality gaps}

The findings show that developing-world e-government IS projects fail due to root causes linked to all seven ITPOSMO design-reality gap dimensions suggested by Heeks (2003). The ITPOSMO management systems and structures dimension had the highest number of root causes, totalling 46. In this dimension, most of the root causes were found to fall under seven of the 18 identified casual factors: inadequate project planning, inadequate project management, inadequate top management support, procurement and contractual issues, inadequate BPM, insufficient change management, and inappropriate organisational management structure. The processes and technology dimensions were the second and third most prominent problematic ITPOSMO dimensions, with 28 and 26 root causes respectively. Figure 20 shows the number of root causes found to be linked to each of the seven ITPOSMO design-reality gap dimensions. 
Figure 20: Number of root causes per ITPOSMO design-reality gap dimension

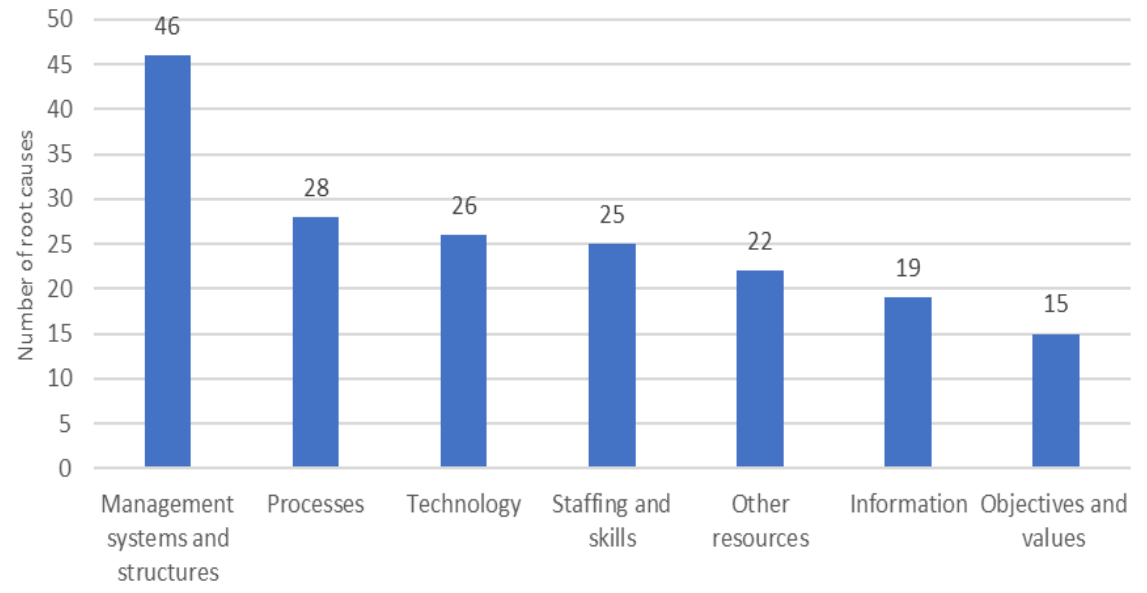

\section{Causal factors}

Among the 18 identified causal factors, inadequate systems requirement engineering was found to have the highest number of root causes, totalling 22. Inadequate project management and missing or incomplete features were the second and third most prominent causal factors, with 19 and 16 root causes respectively. Figure 21 shows the number of root causes per causal factor. The causal factors having a large number of root causes are likely to be the ones that require the most attention in order to mitigate their potential to lead to e-government project failure.

\section{Figure 21: Number of root causes per causal factor}

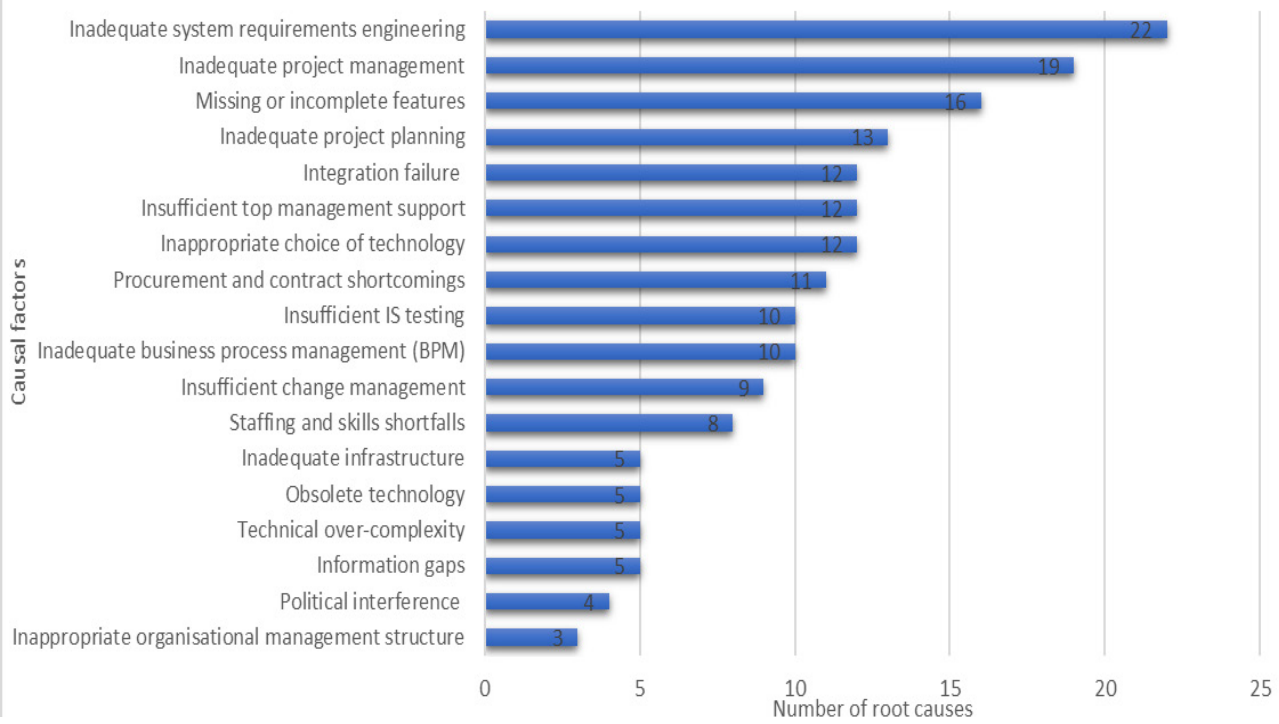


E-government information systems are complex, as they tend to have numerous components serving multiple stakeholders with different needs, views, preferences, and operating environments. This study reveals that e-government IS projects do not fail due to a single reason but rather due to a combination of several factors associated with design-reality gaps. Therefore, the successful implementation of an e-government IS project requires broad multi-dimensional strategies that address all seven potential design-reality gap dimensions.

This study provides both theoretical and practical contributions in the e-government IS domain. From a theoretical perspective, the study extends design-reality gap theory by identifying the root causes of such gaps for each identified cause of e-government IS project failure. From a practical perspective, the study findings may be useful to researchers, policymakers, and practitioners seeking to understand the necessary components of appropriate e-government IS interventions in developing-world settings. Understanding the root causes of problems is essential to developing practical solutions. Future studies can focus on establishing theoretical and methodological frameworks and tools to address the challenges identified in this study.

\section{References}

Abbas, A., Faiz, A., Fatima, A., \& Avdic, A. (2017). Reasons for the failure of government IT projects in Pakistan: A contemporary study. In IEEE (Ed.), 2017 International Conference on Service Systems and Service Management (ICSSSM 2017). https://doi.org/10.1109/ICSSSM.2017.7996223

Afyonluoğlu, M., Aydin, A., Sevil, S. G., Yüksel, E., \& Güngör, M. K. (2014). An e-government project management approach with e-transformation perspective. International Journal of eBusiness and eGovernment Studies, 6(1), 21-33.

Aikins, S. K. (2012). Improving e-government project management: Best practices and critical success factors. In S. K. Aikins (Ed.), Managing e-government projects: Concepts, issues, and best practices (pp. 42-60). IGI Global. https://doi.org/10.4018/978-1-4666-0086-7.ch003

Al-Ahmad, W., Al-Fagih, K., Khanfar, K., Alsamara, K., Abuleil, S., \& Abu-Salem, H. (2009). A taxonomy of an IT project failure: Root causes. International Management Review, 5(1), 93-104.

Al-Khanjari, Z. A., Al-Hosni, N., \& Kraiem, N. (2014). Developing a service oriented e-government architecture towards achieving e-government interoperability. International Journal of Software Engineering and its Applications, 8(5), 29-42. https://doi.org/10.14257/ijseia.2014.8.5.04

Al Salmi, M., Mohtar, S., \& Hasnan, N. (2017). Skills and factors of e-government: Case study of Sultanate of Oman. International Journal of Innovation, Management and Technology, 8(4), 313-319. https://doi.org/10.18178/ijimt.2017.8.4.747

Al-Zwainy, F. M. S., Mohammed, I. A., \& Varouqa, I. F. (2018). Diagnosing the causes of failure in the construction sector using root cause analysis technique. Journal of Engineering, 1804053, 1-12. https://doi.org/10.1155/2018/1804053 
Baguma, R., \& Lubega, J. (2013). Factors for success and failure of e-government projects. In ICEGOV'13: Proceedings of the 7th International Conference on Theory and Practice of Electronic Governance (pp. 194-197). https://doi.org/10.1145/2591888.2591921

Bail, W. (2010). Effective requirements engineering. In SIGAda '10:Proceedings of the ACM SIGAda Annual International Conference on SIGAda. https://doi.org/10.1145/1879063.1879065

Bakunzibake, P., Grönlund, Å., \& Klein, G. O. (2018). E-government implementation in developing countries: Enterprise content management in Rwanda. In H. J. Scholl, O. Glassey, \& M. Janssen (Eds.), Electronic government and electronic participation. IOS Press. https://doi.org/10.3233/978-1-61499-670-5-251

Boota, M. W., Ahmad, N., \& Masoom, A. H. (2014). Requirement engineering issues and their solutions. International Journal of Engineering and Technical Research (IJETR 2014), 2(11), 50-56.

Botchkarev, A., \& Finnigan, P. (2015). Complexity in the context of information systems project management. Organisational Project Management, 2(1), 15-34.

https://doi.org/10.5130/opm.v2i1.4272

Bubenko, J. A. (1995). Challenges in requirements engineering. In IEEE (Ed.), Proceedings of IEEE International Symposium on Requirements Engineering (RE'95) (pp. 160-162). https://doi.org/10.1109/isre.1995.512557

National Audit Office of Tanzania. (2019). Performance audit report on the management of provision of national health insurance services. Ministry of Finance. http://www.nao. go.tz/?wpfb dl=303

Chaudhary, S. (2017). Latest software testing tools and techniques: A review. International Journal of Advanced Research in Computer Science and Software Engineering, 7(5), 538540. https://doi.org/10.23956/ijarcsse/SV7I5/0138

Comins, L. (2020, March 12). eThekwini's billing system shock: Residents slapped with inflated bills. The Mercury. https://www.iol.co.za/mercury/news/ethekwinis-billingsystem-shock-residents-slapped-with-inflated-bills-44685080

Dada, D. (2006). The failure of e-government in developing countries: A literature review. The Electronic Journal of Information Systems in Developing Countries, 26(1), 1-10. https://doi.org/10.1002/j.1681-4835.2006.tb00176.x

Dahiya, D., \& Mathew, S. K. (2018). IT infrastructure capability and e-government system performance: An empirical study. Transforming Government: People, Process and Policy, 12(1), 16-38. https://doi.org/10.1108/TG-07-2017-0038

Dalal, S., \& Chhillar, R. S. (2013). Empirical study of root cause analysis of software failure. ACM SIGSOFT Software Engineering Notes, 38(4), 1-7. https://doi.org/10.1145/2492248.2492263

Damoah, I. S., \&Akwei, C. (2017). Government project failure in Ghana: A multidimensional approach. International Journal of Managing Projects in Business, 10(1), 32-59. https://doi.org/10.1108/IJMPB-02-2016-0017

Dwivedi, Y. K., Wastell, D., Laumer, S., Henriksen, H. Z., Myers, M. D., Bunker, D., Elbanna, A., Ravishankar, M. N., \& Srivastava, S. C. (2014). Research on information systems failures and successes: Status update and future directions. Information Systems Frontiers, 17(1), 143-157. https://doi.org/10.1007/s10796-014-9500-y 
Feldgen, M., \& Clua, O. (2014). Teaching effective requirements engineering for largescale software development with scaffolding. In IEEE (Ed.), 2014 IEEE Frontiers in Education Conference (FIE) proceedings. https://doi.org/10.1109/FIE.2014.7044176

Gartlan, J., \& Shanks, G. (2007). The alignment of business and information technology strategy in Australia. Australasian Journal of Information Systems, 14(2), 113-139. https://doi.org/10.3127/ajis.v14i2.184

Ghapanchi, A., \& Albadvi, A. (2008). A framework for e-government planning and implementation. Electronic Government: An International Journal, 5(1), 71-90. https://doi.org/10.1504/EG.2008.016129

Gilbert, D., Balestrini, P., \& Littleboy, D. (2004). Barriers and benefits in the adoption of e-government. International Journal of Public Sector Management, 17(4), 286-301. https://doi.org/10.1108/09513550410539794

Goedeke, J., Mueller, M., \& Pankratz, O. (2017). Uncovering the causes of information system project failure. In AMCIS 2017 proceedings (pp. 1-10).

Gunawong, P., \& Gao, P. (2017). Understanding e-government failure in the developing country context: A process-oriented study. Information Technology for Development, 23(1), 153-178. https://doi.org/10.1080/02681102.2016.1269713

Hangal, S., \& Lam, M. S. (2002). Tracking down software bugs using automatic anomaly detection. In ICSE '02: Proceedings of the 24th International Conference on Software Engineering (pp. 291-301). https://doi.org/10.1145/581376.581377

Hasan, M. M. (2015). E-government success and failure: A case study of Bangladesh police. Daffodil International University Journal of Science and Technology, 10(1), 61-67.

Heeks, R. (Ed.). (1999). Reinventing government in the information age: International practice in IT-enabled public sector reform (1st ed.). Routledge.

https://doi.org/10.4324/9780203204962

Heeks, R. (2001). Understanding e-governance for development. iGovernment Working Paper 11. https://doi.org/10.2139/ssrn.3540058

Heeks, R. (2003). Most eGovernment-for-development projects fail: How can risks be reduced? iGovernment Working Paper 14. https://doi.org/10.2139/ssrn.3540052

Hofmann,H.F., \& Lehner, F. (2001). Requirements engineering as a success factor in software projects. IEEE Software, 18(4), 58-66. https://doi.org/10.1109/MS.2001.936219

Hossan, C. G., \& Kushchu, I. (2006). Success and failure factors for e-government projects implementation in developing countries: A study on the perception of government officials of Bangladesh. https://www.semanticscholar.org/paper/Success-and-FailureFactors-for-e-Government-in-\%3A-A-Hossan-Habib/2f519f1afb33ed4acc870aa245 9681fce84a2399

Hussain, A., Mkpojiogu, E. O.C., \& Abdullah, I. (2016). Requirements engineering practices in UUMIT centre: An assessment based on the perceptions of in-house software developers. Journal of Telecommunication, Electronic and Computer Engineering, 8(8), 27-32.

Hussain, A., Mkpojiogu, E. O. C., \& Kamal, F. M. (2016). The role of requirements in the success or failure of software projects. International Review of Management and Marketing, 6(S7), 306-311. 
Hussein, R., Shahriza, N., \& Karim, A. (2007). The impact of technological factors on information systems success in the electronic-government context. Business Process Management Journal, 13(5), 613-627. https://doi.org/10.1108/14637150710823110

Imran, A., Gregor, S., \& Turner, T. (2017). e Government management for developing countries (2nd ed.). ACPI.

Khan, N., \& Islamabad, D. E. (2009). Public sector innovation: Case study of e-government projects in Pakistan. The Pakistan Development Review, 48(4), 439-457.

https://doi.org/10.30541/v48i4IIpp.439-457

Lachal, J., Revah-Levy, A., Orri, M., \& Moro, M. R. (2017). Metasynthesis: An original method to synthesize qualitative literature in psychiatry. Frontiers in Psychiatry, 8, 269. https://doi.org/10.3389/fpsyt.2017.00269

Lam, W. (2005). Barriers to e-government integration. Journal of Enterprise Information Management, 18(5), 511-530. https://doi.org/10.1108/17410390510623981

Lau, E. (2003). 5th Global Forum on Reinventing Government, Mexico City, 5 November 2003: Challenges for e-government development. OECD E-government Project.

Layne, K., \& Lee, J. (2001). Developing fully functional e-government: A four stage model. Government Information Quarterly, 18(2), 122-136.

https://doi.org/10.1016/S0740-624X(01)00066-1

Livingston, A. D., Jackson, G., \& Priestley, K. (2001). Root causes analysis: Literature review. HSE Books.

Mansor, Z., \& Ndudi, E. E. (2015). Issues, challenges and best practices of software testing activity. In Recent Advances in Computer Engineering (pp. 42-47), proceedings of ACE 2015, Seoul. https://www.wseas.us/e-library/conferences/2015/Seoul/ACE/ACE-06. pdf

Martin, R. L., \& Montagna, J. M. (2006). Business process reengineering role in electronic government. In D. E. Avison, S. Elliot, J. Krogstie, \& J. Pries-Heje (Eds.) The past and future of information systems: 1976-2006 and beyond: IFIP 19th World Computer Congress, TC-8, Information System Stream, August 21-23, 2006, Santiago, Chile (pp. 77-88). Springer. https://doi.org/10.1007/978-0-387-34732-5

Matte, R. (2017). Bureaucratic structures and organizational performance: A comparative study of Kampala Capital City Authority and National Planning Authority. Journal of Public Administration and Policy Research, 9(1), 1-16. https://doi.org/10.5897/JPAPR2016.0377

Michael, K.A., \& Boniface, K. A. (2014). Inadequate requirements engineering process: A key factor for poor software development in developing nations: A case study. International Journal of Computer, Electrical, Automation, Control and Information Engineering, 8(9), 1572-1575.

Mukherjee, I. (2008). Understanding information system failures from the complexity perspective. Journal of Social Sciences, 4(4), 308-319.

https://doi.org/10.3844/jssp.2008.308.319

Ministry of Works, Transport and Communication (2016). National Information and Communication Technology (ICT) Policy. Government of Tanzania.

Nograsek, J. (2011). Change management as a critical success factor in e-government implementation. Business Systems Research, 2(2), 1-56.

https://doi.org/10.2478/v10305-012-0016-y 
Ojha, S., \& Pandey, I. M. (2017). Management and financing of e-government projects in India: Does financing strategy add value? IIMB Management Review, 20,1-19. https://doi.org/10.1016/j.iimb.2017.04.002

Paradies, M., \& Busch, D. (1988). Root cause analysis at Savannah River Plant nuclear power station. In Conference record for 1988 IEEE Fourth Conference on Human Factors and Power Plants. https://doi.org/10.1109/HFPP.1988.27547

Patanakul, P. (2014). Managing large-scale IS/IT projects in the public sector: Problems and causes leading to poor performance. Journal of High Technology Management Research, 25(1), 21-35. https://doi.org/10.1016/j.hitech.2013.12.004

Pohl, K. (2010). Requirements engineering: Fundamentals, principles, and techniques (1st ed). Springer.

Rahman, S., Rashid, N., Yadlapalli, A., \& Yiqun, L. (2014). Determining factors of e-government implementation: A multi-criteria decision-making approach. In Proceedings - Pacific Asia Conference on Information Systems (PACIS 2014).

Rajala, T., \& Aaltonen, H. (2020). Reasons for the failure of information technology projects in the public sector. In H. Sullivan, H. Dickinson, \& H. Henderson (Eds.), The Palgrave handbook of the public servant (pp. 1-21). Palgrave MacMillan. https://doi.org/10.1007/978-3-030-03008-7 78-1

Rajapakse, J., Van der Vyver, A., \& Hommes, E. (2012). E-government implementations in developing countries: Success and failure, two case studies. In IEEE (Ed.), 2012 IEEE 6th International Conference on Information and Automation for Sustainability (pp. 95-100). https://doi.org/10.1109/ICIAFS.2012.6419888

Palanisamy, R. (2004). Issues and challenges in electronic governance planning. Electronic Government, an International Journal, 1(3), 253-272. https://doi.org/10.1504/EG.2004.005551

Reffat, R. M. (2003). Developing a successful e-government. In The proceedings of the Symposium on E-Government: Opportunities and Challenge, Muscat Municipality (pp $1-13)$.

Sæbø, Ø. (2012). E-government in Tanzania: Current status and future challenges. In H. J. Scholl, M. Janssen, M. A. Wimmer, C. E. Moe, \& L. S. Flak (Eds.), Electronic government: 11th IFIP WG 8.5 International Conference, EGOV 2012, Kristiansand, Norway, September 3-6, 2012. (pp. 198-209).

https://doi.org/10.1007/978-3-642-33489-4 17

Sandelowski, M., Docherty, S., \& Emden, C. (1997). Qualitative metasynthesis: Issues and techniques. Research in Nursing E Health, 20(4), 365-371. https://doi.org/10.1002/ (SICI)1098-240X(199708)20:4<365::AID-NUR9>3.0.CO;2-E

Shah, S. R. A., Khan, A. Z., \& Khalil, D. M. S. (2011). Project management practices in e-government projects: A case study of electronic government directorate (EGD) in Pakistan. International Journal of Business and Social Science, 2(7), 235-243.

Shah, T., \& Patel, S. V. (2014). A review of requirement engineering issues and challenges in various software development methods. International Journal of Computer Applications, 99(15), 36-45. https://doi.org/10.5120/17451-8370

Sun,P.L.,Ku,C.Y., \&Shih,D.H.(2015).An implementation framework for e-government 2.0. Telematics and Informatics, 32(3), 504-520. https://doi.org/10.1016/j.tele.2014.12.003 
Swartz, E. M.J. (2018). Challenges to the implementation of business process re-engineering of the recruitment process in the Ministry of Fisheries and Marine Resources, Namibia. MPA thesis, Faculty of Economic and Management Sciences, University of Stellenbosch. https://scholar.sun.ac.za/handle/10019.1/103566

Sweis, R. J. (2015). An investigation of failure in information systems projects: The case of Jordan. Journal of Management Research, 7(1), 173-185.

https://doi.org/10.5296/jmr.v7i1.7002

Thakur, S., \& Singh, S. (2012). A study of some e-government activities in South Africa. 2012 E-Leadership Conference on Sustainable e-Government and e-Business Innovations (E-LEADERSHIP) (pp. 1-11). https://doi.org/10.1109/e-Leadership.2012.6524704

Tomić, B., \& Brkić, V. S. (2011). Effective root cause analysis and corrective action process. Journal of Engineering Management and Competitiveness (JEMC), 1(1/2), 16-20. http:// www.tfzr.uns.ac.rs/jemc

Toots, M.(2019).Why e-participation systems fail: The case of Estonia's Osale.ee. Government Information Quarterly, 36(3), 546-559. https://doi.org/10.1016/j.giq.2019.02.002

Trkman, P. (2010). The critical success factors of business process management. International Journal of Information Management, 30(2), 125-134.

https://doi.org/10.1016/j.ijinfomgt.2009.07.003

Twizeyimana, J. D., Larsson, H., \& Grönlund, Å. (2018). Egovernment in Rwanda: Implementation, challenges and reflections. The Electronic Journal of E-Government, 16(1), 19-31.

Ullah, S., Iqbal, M., \& Khan, A. M. (2011). A survey on issues in non-functional requirements elicitation. In Proceedings of International Conference on Computer Networks and Information Technology (pp.333-340). https://doi.org/10.1109/ICCNIT.2011.6020890

Urquhart, C. (2010). Systematic reviewing, meta-analysis and meta-synthesis for evidencebased library and information science. Information Research, 15(3). http://informationr. net/ir/15-3/colis7/colis708.html

Verner, J., Sampson, J., \& Cerpa, N. (2008). What factors lead to software project failure? In 2008 Second International Conference on Research Challenges in Information Science (pp. 71-80). https://doi.org/10.1109/RCIS.2008.4632095

Vyas, V., Vyas, S., \& Kundan, A. (2014). Management information system: Information needs of organisation. International Journal of Information E Computation Technology, 4(17), 1903-1908.

Williams, P. M. (2001). Techniques for root cause analysis. Baylor University Medical Center Proceedings, 14(2), 154-157. https://doi.org/10.1080/08998280.2001.11927753

Xia, W., \& Lee, G. (2005). Complexity of information systems development projects: Conceptualization and measurement development. Journal of Management Information Systems, 22(1), 45-83. https://doi.org/10.1080/07421222.2003.11045831

Zakaria, N. H., Haron, A., Sahibuddin, S., \& Harun, M. (2011). Requirement engineering critical issues in public sector software project success factor. International Journal of Information and Electronics Engineering, 1(3), 200-209. https://doi.org/10.7763/IJIEE.2011.V1.32

Zwikael, O. (2014). Top management involvement in project management: Exclusive support practices for different project scenarios. International Journal of Managing Projects in Business, 1(3), 387-403. https://doi.org/10.1108/17538370810883837 